\title{
FUNGSI STRATEGIS DANAU POSO, GANGGUAN KESEIMBANGAN EKOSISTEM, DAN UPAYA PENANGGULANGANNYA
}

\author{
Marianne Reynelda Mamondol \\ Pusat Studi Lingkungan dan Pertanian Berkelanjutan \\ Fakultas Pertanian Universitas Kristen Tentena \\ e-mail : mariannemamondol@gmail.com
}

\begin{abstract}
ABSTRAK
Danau Poso memiliki beberapa fungsi strategis terhadap kehidupan masyarakat yaitu menciptakan iklim mikro, sebagai sumber air yang dapat dimanfaatkan secara langsung oleh masyarakat, lokasi pengembangan perikanan darat, tempat berlangsungnya siklus hidup beberapa biota endemik yang penting, sarana transportasi perairan darat, sebagai penghasil energi listrik, sarana rekreasi dan obyek pariwisata. Beberapa tahun terakhir, Danau Poso mengalami gangguan keseimbangan ekosistem berupa kerusakan yang terjadi pada Daerah Tangkapan Air (DTA) dengan indikator laju erosi dan sedimentasi yang cukup besar serta kerusakan lahan dan sempadan yang semakin meningkat, penurunan kualitas air danau sebagai akibat pencemaran air oleh limbah rumah tangga, pertanian, dan industri, dan terancamnya kelestarian ikan sidat sebagai biota endemik perairan Danau Poso. Upaya penanggulangan gangguan keseimbangan ekosistem dapat dilakukan melalui penyelamatan ekosistem DTA dan Daerah Aliran Sungai (DAS), pengendalian pencemaran, pemantauan, dan evaluasi kualitas air danau secara berkala, konservasi sumberdaya dan keanekaragaman hayati pada ekosistem danau, pengaturan pengelolaan terhadap pemanfaatan sumberdaya air danau, dan peningkatan peran dan partisipasi masyarakat dalam penyelamatan ekosistem danau.
\end{abstract}

Kata kunci : Danau Poso, fungsi strategis, gangguan keseimbangan ekosistem, upaya penanggulangan

\section{ABSTRACT}

Poso Lake has several strategic functions on society livelihood, i.e. to create micro climate, as the source of water which can be directly benefited by people, the location for developing inland water fisheries, the site for conducting life cycles for some important endemic biotes, an inland water transportation facility, the producer of electrical energy, recreation amenities and tourism object. In recent years, Poso Lake has experienced disturbance of ecosystem balance in the form of degradations that happen at water catchment area with indicators of high levels for erosion and sedimentation, the decreasing of water quality as the impact of pollution incurred by household, agriculture, and industry wastes, and threatens on the sustainability of eel fish as Poso Lake's endemic biote. Efforts to overcome the disturbance of ecosystem ballance can be implemented through rescuing the water catchment area and watershed ecosystems, pollution control, periodic monitoring and evaluation on water quality, conservation on resources and biodiversity at lake ecosystem, management regulation for water resource using, and the enhancement of society's role and participation in salvaging lake ecosystem.

Keywords : Poso Lake, strategic functions, disturbance of ecosystem ballance, overcoming efforts 


\section{PENDAHULUAN}

Danau Poso merupakan ekosistem perairan yang memiliki keunikan dan keindahan tersendiri, serta menjadi obyek kebanggaan masyarakat Kabupaten Poso maupun Provinsi Sulawesi Tengah. Danau Poso adalah danau terluas ketiga di Indonesia setelah Danau Toba di Sumatera Utara dan Danau Towuti di Sulawesi Selatan, serta danau terdalam ketiga setelah Danau Matano di Sulawesi Selatan dan Danau Toba di Sumatera Utara. Berbagai potensi sumberdaya alam dan budaya dimiliki oleh Danau Poso, di antaranya hamparan pasir berwarna kuning dan putih di sepanjang perairan danau, keberadaan ikan endemik sidat (Anguilla spp), serta kearifan lokal (local wisdom) yang dimiliki oleh masyarakat di sekitarnya.

Danau Poso telah dimanfaatkan untuk beragam kepentingan masyarakat dan industri, yaitu sebagai sumber air, lokasi wisata, dan pengembangan perikanan darat. Akan tetapi dewasa ini Danau Poso juga menghadapi banyak permasalahan yang cukup serius yang mengancam keberadaan dan kelestariannya. Beberapa tahun terakhir, Danau Poso mengalami laju erosi dan sedimentasi yang cukup tinggi akibat degradasi Daerah Tangkapan Air (DTA) dan meluasnya lahan kritis di sekitar kawasan danau (Isrun, 2009), penurunan kualitas air akibat polusi limbah domestik, dan penurunan keberadaan biota endemik ikan sidat akibat terputusnya jalur ruaya (migrasi) ikan (KLH, 2014).

Berdasarkan Kesepakatan Bali 2009 tentang Pengelolaan Danau telah ditetapkan 15 danau prioritas di Indonesia yang akan ditangani bersama secara terpadu, berwawasan lingkungan dan berkelanjutan untuk periode tahun 2010 - 2014. Danau Poso termasuk di antara ke - 15 danau yang mendapatkan prioritas penyelamatan akibat ancaman kerusakan yang semakin besar. Penetapan danau prioritas tersebut dilandaskan pada beberapa hal yaitu tingkat kerusakan danau, pemanfaatan danau, komitmen pemerintah daerah dan masyarakat dalam pengelolaan danau, fungsi strategis danau bagi kepentingan nasional, keanekaragaman hayati, dan tingkat risiko bencana. Dengan demikian pengembangan dan pemanfaatan potensi Danau Poso memerlukan pula upaya-upaya untuk mempertahankan, melestarikan, dan memulihkan fungsi danau berdasarkan keseimbangan ekosistem.

Tulisan ini menguraikan fungsi-fungsi strategis Danau Poso, gangguan-gangguan terhadap keseimbangan ekosistem danau, serta upaya-upaya penanggulangan yang dapat dilakukan untuk mengurangi tekanan ekologis terhadap Danau Poso akibat aktivitas manusia. Pengelolaan yang intensif dan terpadu diperlukan agar keberadaan dan fungsi danau tetap berkelanjutan pada masa sekarang maupun mendatang.

\section{KARAKTERISTIK EKOSISTEM DANAU POSO}

Secara geografis Danau Poso terletak pada koordinat $1^{\circ} 44^{\prime}-2^{\circ} 04^{\prime}$ Lintang Selatan dan $120^{\circ} 32^{\prime}-120^{\circ} 43^{\prime}$ Bujur Timur, berjarak sekitar 55 km di selatan Kota Poso. Danau Poso merupakan danau tektonik yang terbentuk akibat aktivitas tektonik (patahan) di kawasan sekitarnya. Danau Poso memiliki luas sebesar \pm 36.677 ha, ketinggian 600 meter di atas permukaan laut, dan kedalaman maksimum hingga 384,6 meter. Daerah tangkapan air (DTA) atau Water Catchment Area (WCA) Danau Poso mencapai luas 148.546,41 ha yang berbatasan 
dengan Pegunungan Verbeek di bagian selatan, Pegunungan Fennema di sebelah barat, dan Pengunungan Pompangeo di sebelah timur (Lukman dan Ridwansyah, 2009). Melihat perbandingan luas danau dengan luas DTA-nya, maka dapat dikatakan bahwa Danau Poso memiliki potensi sumber air yang memadai karena didukung oleh DTA sebesar kira-kira 4 kali luas permukaan danau (Dewanto et al, 2012). Sebagai pembanding, Danau Lindu yang juga berada di Sulawesi Tengah memiliki DTA yang besarnya 15,9 kali luas permukaan danau (Lukman dan Ridwansyah, 2003).
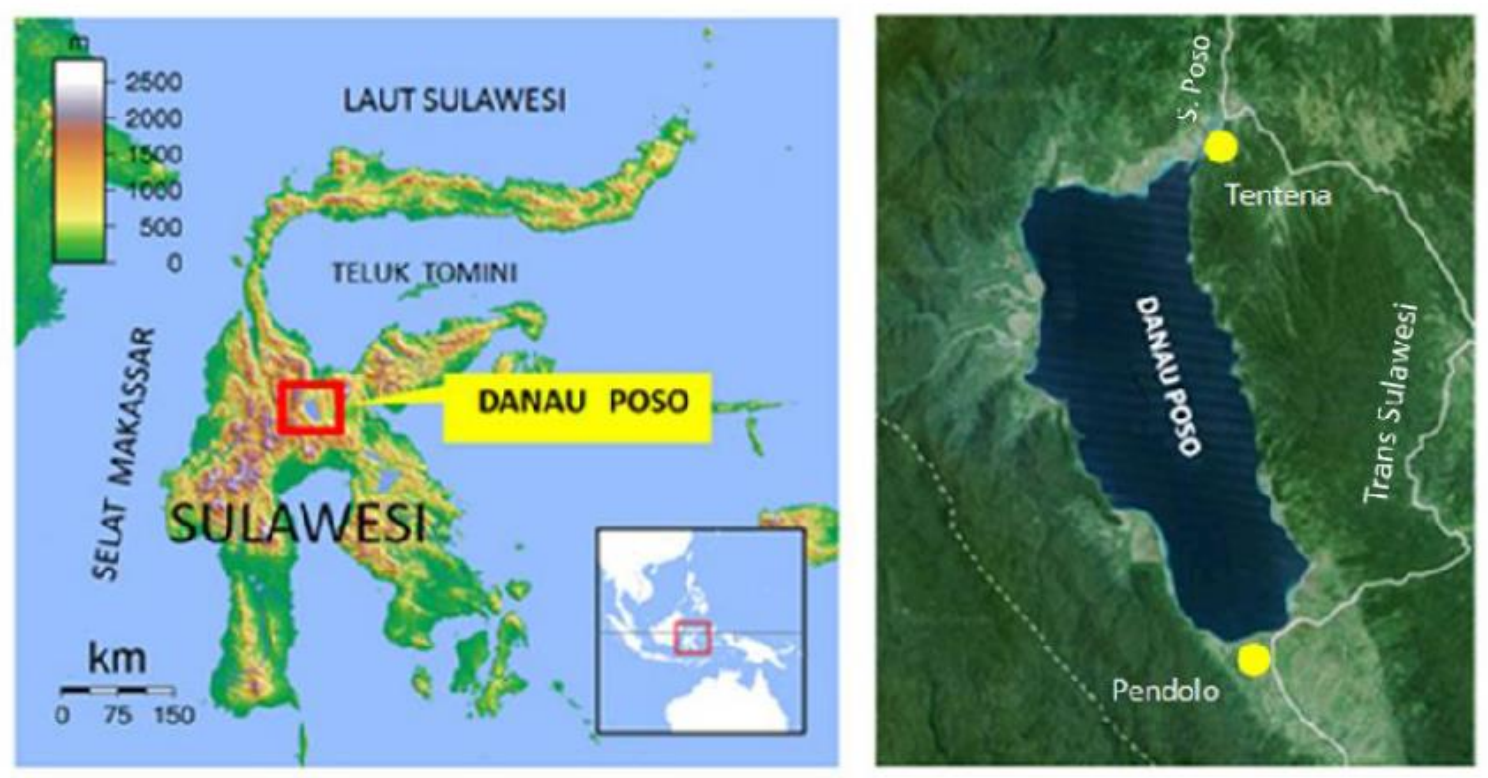

\section{Gambar 1. Peta Lokasi Danau Poso}

Berdasarkan klasifikasi iklim menurut Schmidt dan Ferguson, Danau Poso memiliki tipe iklim A dengan curah hujan rata-rata 3.284,16 mm/tahun dan suhu harian rata-rata berkisar antara $19-32^{\circ} \mathrm{C}$. Curah hujan yang cukup tinggi tersebut mempengaruhi ketinggian permukaan air danau (Lukman dan Ridwansyah, 2009). Secara hidrologis air Danau Poso berasal dari curah hujan, air tanah, dan air permukaan. Terdapat 91 sungai yang menjadi inlet (aliran masuk) bagi Danau Poso, di mana Danau Poso memperoleh suplai air terutama dari beberapa sungai besar yaitu Sungai Meko, Kodina, Panjo, Owini, Salukaia, dan Wimbi. Adapun outlet (aliran keluar) Danau Poso ialah Sungai Poso yang mengalir sepanjang $52 \mathrm{~km}$ dan bermuara di Teluk Tomini (KLH, 2014).

Pada umumnya daerah sekitar Danau Poso memiliki topografi perbukitan dan pegunungan dengan elevasi antara 400 - 1.200 meter dengan kemiringan lereng $15-40 \%$. Daerah Aliran Sungai (DAS) Poso dibagi menjadi 3 bagian, yaitu :

1) Daerah hulu, merupakan daerah dengan kemiringan lebih dari $25 \%$ atau cukup terjal. Di bagian atas hulu, yang berada di lereng pegunungan, kemiringan bahkan mencapai lebih dari $40 \%$.

2) Daerah tengah, merupakan daerah dengan kemiringan sedang yang rata-rata sebesar $8 \%$. Di beberapa bagian dijumpai kemiringan yang mencapai $15 \%$. Daerah tengah ini merupakan kawasan pertanian padi sawah, tegalan, dan semak belukar. 
3) Daerah hilir, merupakan daerah dataran rendah dengan kemiringan kurang dari $2 \%$. Di bagian hilir ini terdapat persawahan, tegalan, dan kebun (KLH, 2014).

Secara administratif, wilayah pesisir Danau Poso merupakan bagian dari 5 kecamatan, yaitu Kecamatan Pamona Utara, Pamona Puselemba, Pamona Barat, Pamona Tenggara, dan Pamona Selatan. Terdapat 36 desa/kelurahan dari kelima kecamatan tersebut yang tepat berada di pesisir Danau Poso. Kecamatan Pamona Selatan merupakan kecamatan dengan jumlah desa terbanyak yang terdapat di pesisir danau, yaitu sebanyak 12 desa. Sementara itu Kecamatan Pamona Puselemba merupakan kecamatan dengan wilayah terluas yang masuk dalam kawasan Danau Poso, yaitu sebesar 561,38 $\mathrm{km}^{2}$ atau $37 \%$ dari keseluruhan kawasan pesisir Danau Poso.

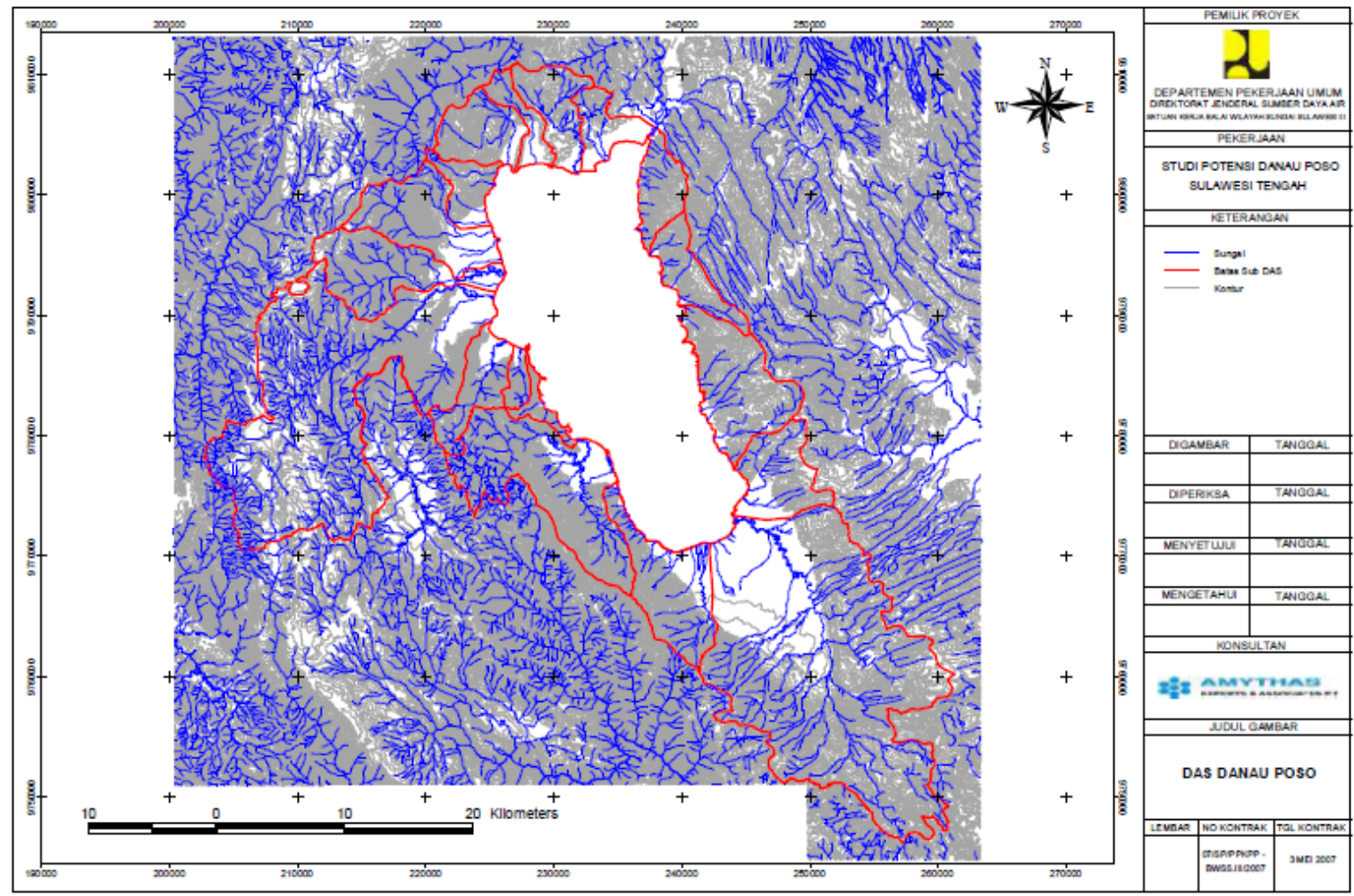

Gambar 2. Peta Topografi DTA Danau Poso

\section{FUNGSI STRATEGIS DANAU POSO}

Danau Poso memiliki beberapa fungsi strategis yang berkontribusi terhadap kehidupan masyarakat di sekitarnya. Fungsi-fungsi tersebut ialah sebagai berikut :

1) Sebagai pencipta iklim mikro

Keberadaan suatu ekosistem danau dapat mempengaruhi curah hujan dan kelembaban daerah di sekitarnya. Curah hujan (3.284,16 mm/tahun) dan kelembaban udara (82,58 \%) yang cukup tinggi (BPS, 2017) memberikan ciri khas udara yang sejuk bagi daerah Tentena dan daerah lainnya yang terletak di sekeliling perairan Danau Poso.

2) Sebagai sumber air yang dapat dimanfaatkan secara langsung oleh masyarakat 
Air danau dimanfaatkan oleh masyarakat untuk memenuhi kebutuhan air bersih rumah tangga, atau dimanfaatkan pula sebagai pengairan bagi usaha pertanian dan perkebunan rakyat.

3) Sebagai lokasi pengembangan perikanan darat

Danau Poso merupakan wilayah perairan yang dimanfaatkan masyarakat untuk kegiatan perikanan tangkap maupun budidaya perikanan dengan sistem karamba dan jaring apung (floating net).

4) Sebagai tempat berlangsungnya siklus hidup beberapa biota endemik yang penting Di Danau Poso terdapat beberapa jenis ikan seperti ikan gabus (Channa striata), ikan mujair (Oreochromis mossambicus), ikan mas (Cyprinus carpio), ikan rono (Oryzias nigricans), dan ikan sidat/sogili (Anguilla sp). Terdapat pula ikan buntingi (Adrianichtys poptae dan Adrianichtys kruyti) yang sekarang terancam punah dan telah masuk kategori Red List of Threatened Species.

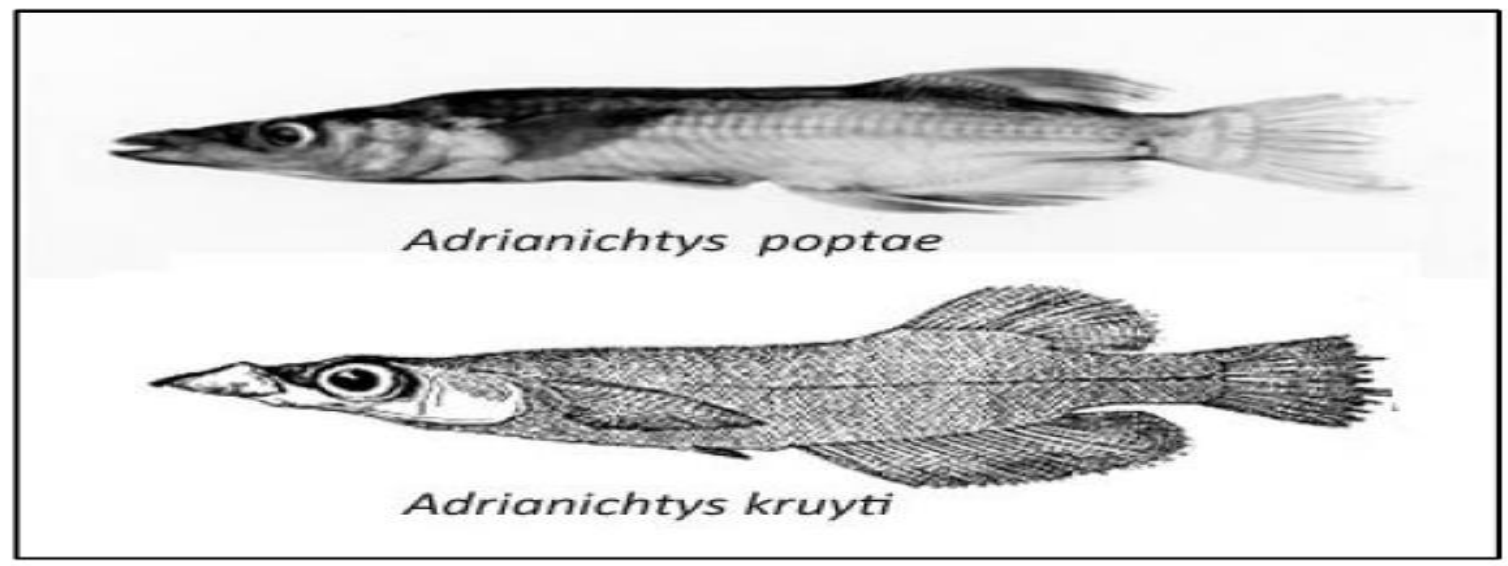

Gambar 3. Ikan Buntingi

Sementara itu ikan sidat merupakan ikan dengan karakteristik unik, yaitu melakukan migrasi (ruaya) untuk keperluan reproduksinya. Larva sidat yang baru menetas di laut dalam akan berenang kembali ke perairan darat melalui melalui muara sungai untuk selanjutnya tumbuh dan berkembang sampai ukuran dewasa di habitat perairan tawar. Aktivitas ruaya dari perairan darat untuk kembali ke laut (downstream migration) mencapai puncaknya sekitar bulan April. Hal ini terkait dengan ketinggian permukaan air Danau Poso yang meningkat akibat curah hujan yang tinggi pada bulan tersebut.

5) Sebagai sarana transportasi perairan darat

Danau Poso merupakan sarana transportasi perairan darat yang masih tetap berfungsi hingga sekarang. Melalui danau, berbagai hasil pertanian dari desa-desa di sekitarnya diangkut ke Kota Tentena untuk dipasarkan. Perahu-perahu kecil yang disebut katinting merupakan alat transportasi perairan yang khas bagi masyarakat yang bermukim di sekitar Danau Poso.

6) Sebagai penghasil energi listrik

Perairan Danau Poso merupakan penghasil energi listrik melalui Pembangkit Listrik Tenaga Air (PLTA) di Sulewana, Pamona Utara yang memanfaatkan aliran Sungai Poso. PLTA 
Sulewana yang beroperasi penuh sejak tahun 2016 dapat memasok daya listrik sebesar 65 megawatt untuk Provinsi Sulawesi Tengah.

7) Sebagai sarana rekreasi dan obyek pariwisata

Danau Poso memiliki beberapa lokasi tujuan wisata yang menarik, di antaranya ialah :

a. Air terjun Saluopa, terletak di sebelah barat Danau Poso, berjarak sekitar $12 \mathrm{~km}$ sebelah barat Kota Tentena, memiliki 12 tingkat aliran air yang sangat deras, jernih, dan sejuk.

b. Pantai Siuri, terletak di sebelah barat tepian Danau Poso, memiliki karakteristik pasir putih dan kuning pada pantainya, air danau yang jernih, dan udara yang sejuk.

c. Goa Pamona, terletak di sebelah barat tepian Danau Poso dan merupakan peninggalan prasejarah yang berfungsi sebagai tempat pekuburan pada zaman budaya megalith. Mulut goa menghadap ke selatan dengan lebar 2,4 meter, kedalaman goa 80 meter, dan di dalamnya terdapat 8 buah kamar tempat menyimpan kerangka manusia serta bekal kuburnya. Menurut sejarah, kamar pertama hingga keempat merupakan benteng raja suku Pamona yang dipakai sebagai tempat berlindung pada saat perang.

d. Goa Latea, terletak di sebelah timur Danau Poso, berada pada tebing bukit kapur yang diperkirakan usianya telah mencapai 30.000 tahun. Goa ini dijadikan sebagai tempat pekuburan suku Pamona pada masa lampau, namun sistem pekuburan ini berakhir sejak abad ke -19 . Situs ini memiliki benda cagar budaya berupa 4 pasang peti dan 36 buah tengkorak. Pada tahun 1994 situs ini dipugar oleh Direktorat Perlindungan dan Pembinaan Peninggalan Bersejarah dan Purbakala.

e. Watu Mpangasa Angga, merupakan sebuah batu yang menurut legenda digunakan oleh makhluk halus untuk mengasah benda tajam. Letaknya di sebelah timur pantai Danau Poso.

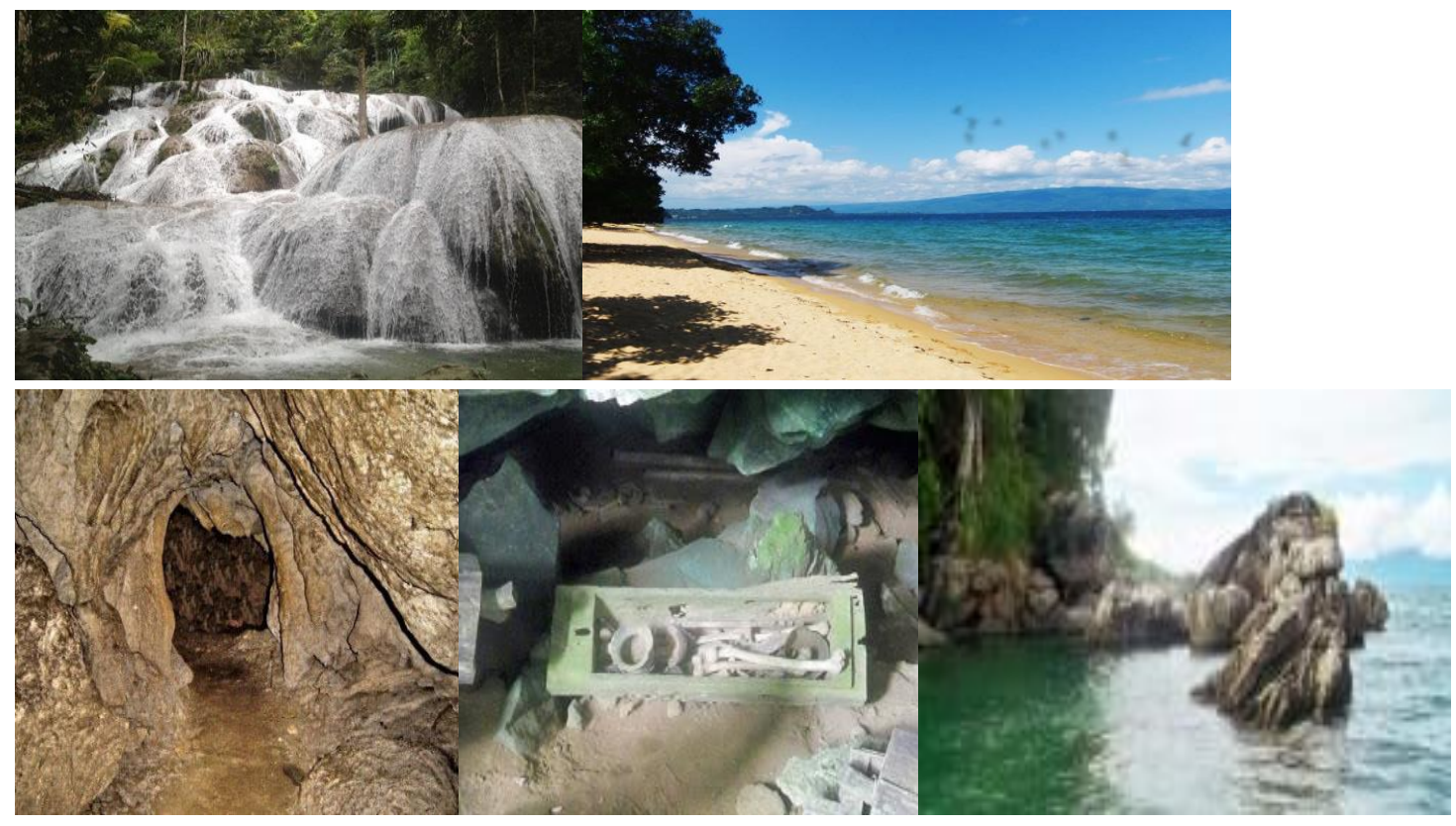

Gambar 4. Beberapa Obyek Wisata di Sekitar Danau Poso 


\section{GANGGUAN KESEIMBANGAN EKOSISTEM DANAU POSO}

Gangguan terhadap keseimbangan ekosistem Danau Poso dibagi ke dalam tiga kelompok, yaitu kerusakan daerah tangkapan air (DTA), penurunan kualitas air danau, dan ancaman terhadap keberadaan ikan sidat sebagai ikan endemik Danau Poso.

1) Kerusakan Daerah Tangkapan Air (DTA)

a. Laju erosi dan sedimentasi

Salah satu indikator kerusakan daerah tangkapan air (DTA) Danau Poso ialah laju erosi dan sedimentasi. Erosi dan sedimentasi pada umumnya disebabkan oleh pola pemanfaatan lahan yang belum sepenuhnya sesuai dengan fungsi dan peruntukannya, aktivitas perladangan tradisional yang masih terus berlangsung, dan terjadinya perambahan hutan pada kawasan hutan negara berupa hutan lindung, cagar alam, dan hutan produksi (KLH, 2011).

Hasil penelitian Isrun (2009) dari Fakultas Pertanian Universitas Tadulako Palu menunjukkan laju erosi dan sedimentasi pada DTA Danau Poso sebagai berikut :

Tabel 1. Laju Erosi dan Sedimentasi pada DTA Danau Poso

\begin{tabular}{|c|c|c|c|c|c|c|}
\hline No. & Sub DTA & $\begin{array}{c}\text { Luas Sub } \\
\text { DTA } \\
\text { (ha) }\end{array}$ & $\begin{array}{c}\text { Panjang } \\
\text { Sungai } \\
\text { Utama } \\
(\mathrm{km})\end{array}$ & $\begin{array}{c}\text { Kemiringan } \\
\text { Sungai } \\
(\%)\end{array}$ & $\begin{array}{c}\text { Laju Erosi } \\
\text { (ton/ha/tahun) }\end{array}$ & $\begin{array}{c}\text { Laju } \\
\text { Sedimentasi } \\
\text { Sungai } \\
\text { (ton/ha/tahun) }\end{array}$ \\
\hline 1. & Kodina-Boe & $48.875,14$ & 38,58 & 1,30 & 57,98 & 12,14 \\
\hline 2. & Bancea-Panjo & $13.768,98$ & 25,17 & 2,02 & 36,37 & 9,12 \\
\hline 3. & Taipa & $3.727,95$ & 12,15 & 9,84 & 14,89 & 5,39 \\
\hline 4. & Meko & $46.793,16$ & 54,89 & 2,14 & 50,90 & 13,49 \\
\hline 5. & Salukaia & $7.108,53$ & 16,31 & 7,35 & 18,85 & 6,69 \\
\hline 6. & Toinasa & $7.826,36$ & 12,45 & 8,62 & 25,05 & 9,15 \\
\hline 7. & $\begin{array}{l}\text { Saluopa- } \\
\text { Mayakeli }\end{array}$ & $7.589,51$ & 5,64 & 0,92 & 42,39 & 6,91 \\
\hline 8. & Peura-Sangele & $3.497,26$ & 5,30 & 11,28 & 14,89 & 5,47 \\
\hline \multirow[t]{2}{*}{9.} & Dulumai-Tokilo & $9.359,51$ & 8,59 & 2,85 & 25,20 & 7,13 \\
\hline & Total Luas DTA & $148.546,41$ & & & & \\
\hline
\end{tabular}

Sumber : Isrun (2009)

Data pada tabel menunjukkan bahwa laju erosi tertinggi terjadi pada Sub DTA KodinaBoe (57,98 ton/ha/tahun) dan Sub DTA Meko (50,90 ton/ha/tahun), sedangkan laju sedimentasi tertinggi terjadi pada Sub DTA Meko (13,49 ton/ha/tahun) dan Sub DTA Kodina-Boe (12,14 ton/ha/tahun).

Faktor utama penyebab tingginya laju erosi pada wilayah Kodina dan Meko ialah tingkat kerusakan lahan, panjang sungai utama, dan kemiringan lereng (kelas lereng IV). Hal ini ditunjang oleh kondisi lahan dalam bentuk lahan terbuka serta curah hujan rata-rata di atas $100 \mathrm{~mm} /$ bulan. Sementara itu tingginya laju sedimentasi yang berasal dari wilayah Meko dan Kodina berkaitan dengan percepatan pendangkalan, terutama pada segmen sungai dan danau di kawasan sub DTA tersebut. Proses pendangkalan menyebabkan kapasitas penampungan air pada danau menjadi berkurang, sehingga airnya mudah meluap pada saat terjadi hujan dengan intensitas tinggi pada waktu yang 
lama. Sebaliknya pada musim kemarau permukaan air danau cepat sekali menurun karena berkurangnya debit air.

Luas DTA terutama berpengaruh terhadap debit aliran air yang masuk ke danau dan pada akhirnya berpengaruh pula pada debit aliran yang keluar danau. Telah dijelaskan bahwa potensi sumber air Danau Poso cukup besar karena luas DTA yang mencapai 4 kali luas permukaan danau, namun luasan DTA juga akan berpengaruh terhadap tingkat sedimentasi danau.

Lukman dan Ridwansyah (2009) menyatakan bahwa kawasan hutan yang melingkupi DTA Danau Poso mencapai $40 \%$, terdiri dari kawasan hutan lindung dan penyangga. Kawasan pemanfaatan mencapai $60 \%$, berupa areal penanaman tanaman tahunan dan semusim serta pemukiman penduduk. Penggunaan lahan untuk kawasan budidaya yang cukup luas perlu mendapatkan perhatian, dikarenakan kondisi tersebut cenderung menjadi ancaman kelestarian perairan danau. Luas kawasan budidaya pada DTA Danau Poso sebesar 74.275 ha ialah dua kali lipat luas perairan danau (36.677 ha), sedangkan struktur tanah di pegunungan yang berada di DTA Danau Poso umumnya kurang kompak dan agak lepas sehingga mudah longsor (Pangesti et al, 1995). Kejadian banjir sesaat dengan debit cukup besar akan membawa material sedimen masuk ke sungai, yang kemudian selain terendapkan di bagian dataran juga akan masuk ke danau dan menyebabkan sedimentasi pada danau.

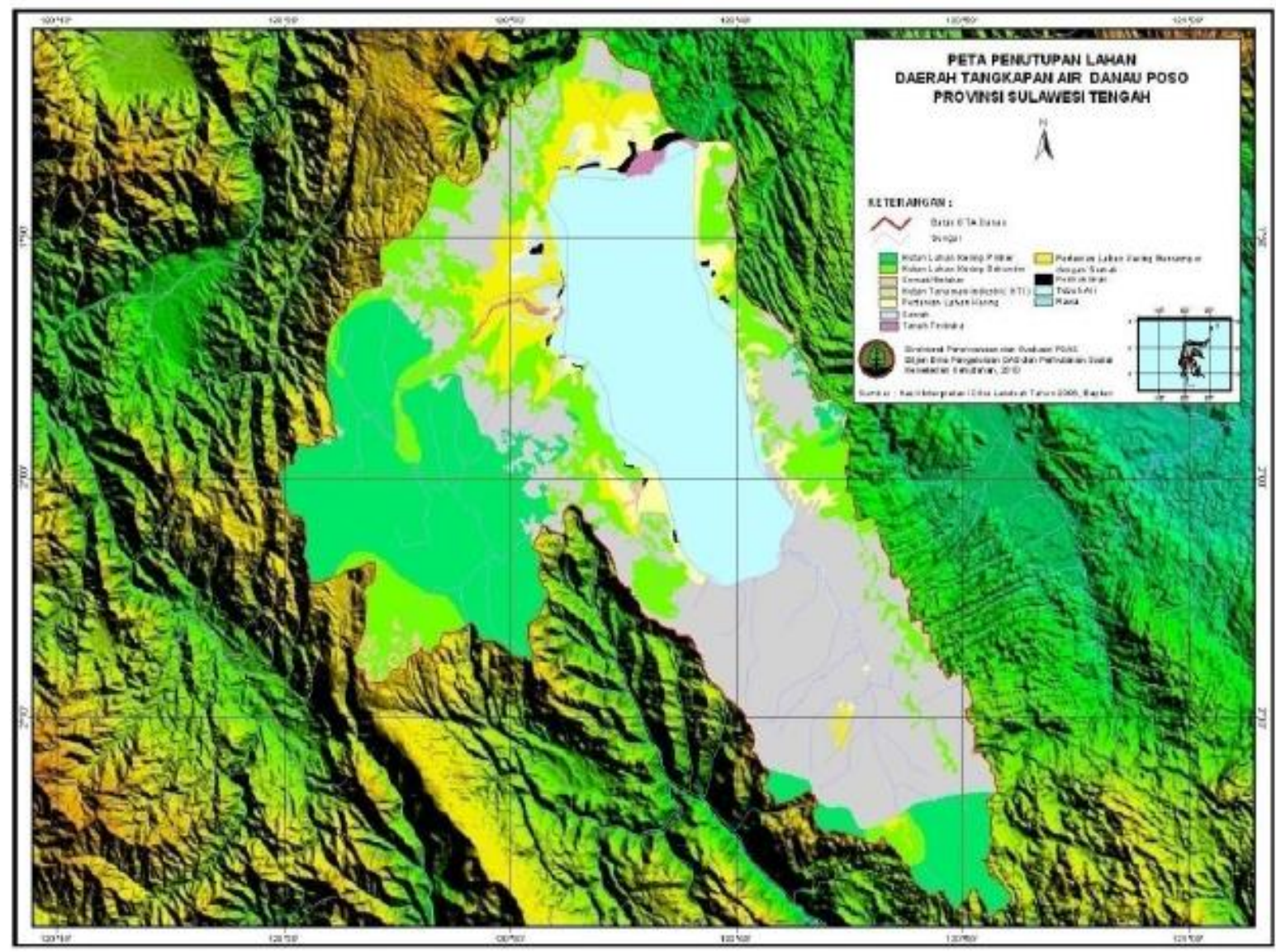

Gambar 5. Peta Penutupan Lahan DTA Danau Poso 
Tingkat erosi akibat pemanfaatan lahan di DTA dan akumulasi material sedimen diduga terjadi terutama di sisi selatan dan barat danau yang menjadi muara sungai-sungai yang menjadi inlet utama Danau Poso, yaitu Sungai Kodina dan Sungai Meko.

Menurut hasil pengukuran yang dilakukan oleh ahli geologi Belanda pada 7 Oktober 1900 dengan menggunakan kawat ukur, kedalaman maksimum Danau Poso ialah 440 meter. Penelitian yang dilakukan oleh Lukman dan Ridwansyah (staf peneliti pada Puslit Limnologi LIPI) bulan April 2007 menunjukkan bahwa kedalaman maksimum Danau Poso ialah 384,6 meter. Perbedaan angka kedalaman danau sebesar 55,4 meter tersebut kemungkinan terjadi karena adanya perbedaan metode pengukuran antara para peneliti. Namun demikian, identifikasi ulang dapat dilakukan untuk mengevaluasi kedalaman danau, karena indikasi telah berkurangnya kedalaman danau dapat saja terjadi.

b. Tingkat kerusakan lahan pada DTA

Pada DTA Danau Poso terdapat 9 pola penggunaan lahan yaitu hutan primer, hutan sekunder, sawah, semak belukar, kebun campuran, tegalan, padang rumput, lahan terbuka, dan pemukiman penduduk. Hasil analisis tingkat kerusakan lahan menunjukkan bahwa umumnya daerah usaha pertanian berada pada tingkat kerusakan agak rusak (AR) sampai rusak (R), sedangkan lahan terbuka pada semua sub DTA berstatus rusak, baik pada lereng dengan kemiringan 25 - $45 \%$ maupun di atas $40 \%$ (Isrun, 2009).

Berdasarkan Tabel 2 diketahui bahwa kerusakan lahan di kawasan DTA Danau Poso berada pada tingkat kerusakan (degradasi) mulai dari agak rusak (AR) hingga rusak (R). Pada kawasan hutan primer atau hutan rapat, kondisi lahan masih tergolong baik (B). Akan tetapi pada kawasan hutan sekunder atau hutan jarang, kondisi agak rusak (AR) hingga rusak (R) terdapat pada Sub DTA Kodina dan Sub DTA Meko. Pada kedua Sub DTA tersebut juga terdapat kondisi kawasan semak belukar yang agak rusak (AR) pada kemiringan lereng $25-40 \%$.

Secara umum, bagian tengah dan hilir Sub DTA sekitar kawasan Danau Poso yang dinilai agak rusak (AR) hingga rusak (R) berada pada daerah berlereng curam (25 $40 \%$ ) sampai dengan sangat curam (> $40 \%$ ) dengan tipe penutupan lahan berupa kebun campuran, tegalan, padang rumput, dan lahan terbuka (tanah gundul). Kondisi lahan dengan tingkat degradasi agak rusak (AR) hingga rusak (R) membutuhkan perhatian dari semua pihak karena pada wilayah-wilayah tersebut terdapat aktivitas-aktivitas yang mengarah pada kerusakan ekosistem DTA. 
Tabel 2. Tingkat Kerusakan Lahan pada Kawasan Danau Poso

\begin{tabular}{|c|c|c|c|c|c|c|c|c|c|}
\hline \multirow{2}{*}{$\begin{array}{l}\text { Penggunaan } \\
\text { Lahan }\end{array}$} & \multicolumn{9}{|c|}{ Tingkat Kerusakan } \\
\hline & 1 & 2 & 3 & 4 & 5 & 6 & 7 & 8 & 9 \\
\hline \multicolumn{10}{|l|}{ Hutan Primer } \\
\hline \multicolumn{10}{|l|}{ Lereng : } \\
\hline $25-40 \%$ & B & B & B & B & B & $\mathrm{B}$ & - & - & - \\
\hline$>40 \%$ & B & $\mathrm{B}$ & B & B & B & $\mathrm{B}$ & - & - & - \\
\hline \multicolumn{10}{|l|}{ Hutan Sekunder } \\
\hline Lereng : & & & & & & & & & \\
\hline $25-40 \%$ & AR & $\mathrm{B}$ & B & $\mathrm{AR}$ & $\mathrm{B}$ & B & B & B & - \\
\hline$>40 \%$ & $\mathrm{R}$ & B & B & $\mathrm{R}$ & B & B & B & B & - \\
\hline Sawah & B & B & $\mathrm{B}$ & $\mathrm{B}$ & $\mathrm{B}$ & $\mathrm{B}$ & $\mathrm{B}$ & $\mathrm{B}$ & $\mathrm{B}$ \\
\hline \multicolumn{10}{|l|}{ Semak Belukar } \\
\hline Lereng : & & & & & & & & & \\
\hline $25-40 \%$ & AR & - & B & $\mathrm{AR}$ & B & B & B & B & - \\
\hline$>40 \%$ & $\mathrm{~B}$ & - & $\mathrm{B}$ & $\mathrm{B}$ & $\mathrm{B}$ & $\mathrm{B}$ & $\mathrm{B}$ & $\mathrm{B}$ & - \\
\hline \multicolumn{10}{|l|}{ Kebun Campuran } \\
\hline Lereng : & & & & & & & & & \\
\hline $25-40 \%$ & $\mathrm{R}$ & AR & AR & $\mathrm{R}$ & AR & AR & $\mathrm{AR}$ & $\mathrm{AR}$ & $\mathrm{AR}$ \\
\hline$>40 \%$ & $\mathrm{R}$ & $\mathrm{AR}$ & AR & $\mathrm{R}$ & $\mathrm{AR}$ & AR & $\mathrm{AR}$ & $\mathrm{R}$ & $\mathrm{AR}$ \\
\hline \multicolumn{10}{|l|}{ Tegalan } \\
\hline Lereng : & & & & & & & & & \\
\hline $25-40 \%$ & $\mathrm{R}$ & - & AR & - & - & - & $\mathrm{AR}$ & - & - \\
\hline$>40 \%$ & $\mathrm{R}$ & - & AR & - & - & - & B & - & - \\
\hline \multicolumn{10}{|l|}{ Padang Rumput } \\
\hline Lereng : & & & & & & & & & \\
\hline $25-40 \%$ & AR & - & AR & AR & - & - & $\mathrm{AR}$ & - & - \\
\hline$>40 \%$ & AR & - & AR & B & - & - & $\mathrm{B}$ & - & - \\
\hline \multicolumn{10}{|l|}{ Lahan Terbuka } \\
\hline Lereng : & & & & & & & & & \\
\hline $25-40 \%$ & $\mathrm{R}$ & $\mathrm{R}$ & $\mathrm{R}$ & $\mathrm{R}$ & - & - & $\mathrm{R}$ & - & - \\
\hline$>40 \%$ & $\mathrm{R}$ & $\mathrm{R}$ & $\mathrm{R}$ & $\mathrm{R}$ & - & - & $\mathrm{R}$ & - & - \\
\hline Pemukiman & $\mathrm{AR}$ & $\mathrm{B}$ & $\mathrm{B}$ & $\mathrm{AR}$ & B & $\mathrm{B}$ & $\mathrm{AR}$ & $\mathrm{B}$ & $\mathrm{B}$ \\
\hline
\end{tabular}

Sumber : Isrun (2009)

Keterangan $\quad:$ AR $=$ Agak Rusak, $\mathrm{B}=$ Baik, $\mathrm{R}=$ Rusak

$1=$ Sub DTA Kodina, 2 = Sub DTA Bancea-Panjo, 3 = Sub DTA Taipa, 4 = Sub DTA Meko,

$5=$ Sub DTA Salukaia, $6=$ Sub DTA Toinasa, $7=$ Sub DTA Saluopa-Mayakeli,

$8=$ Sub DTA Peura-Sangele, $9=$ Sub DTA Tokilo-Dulumai 


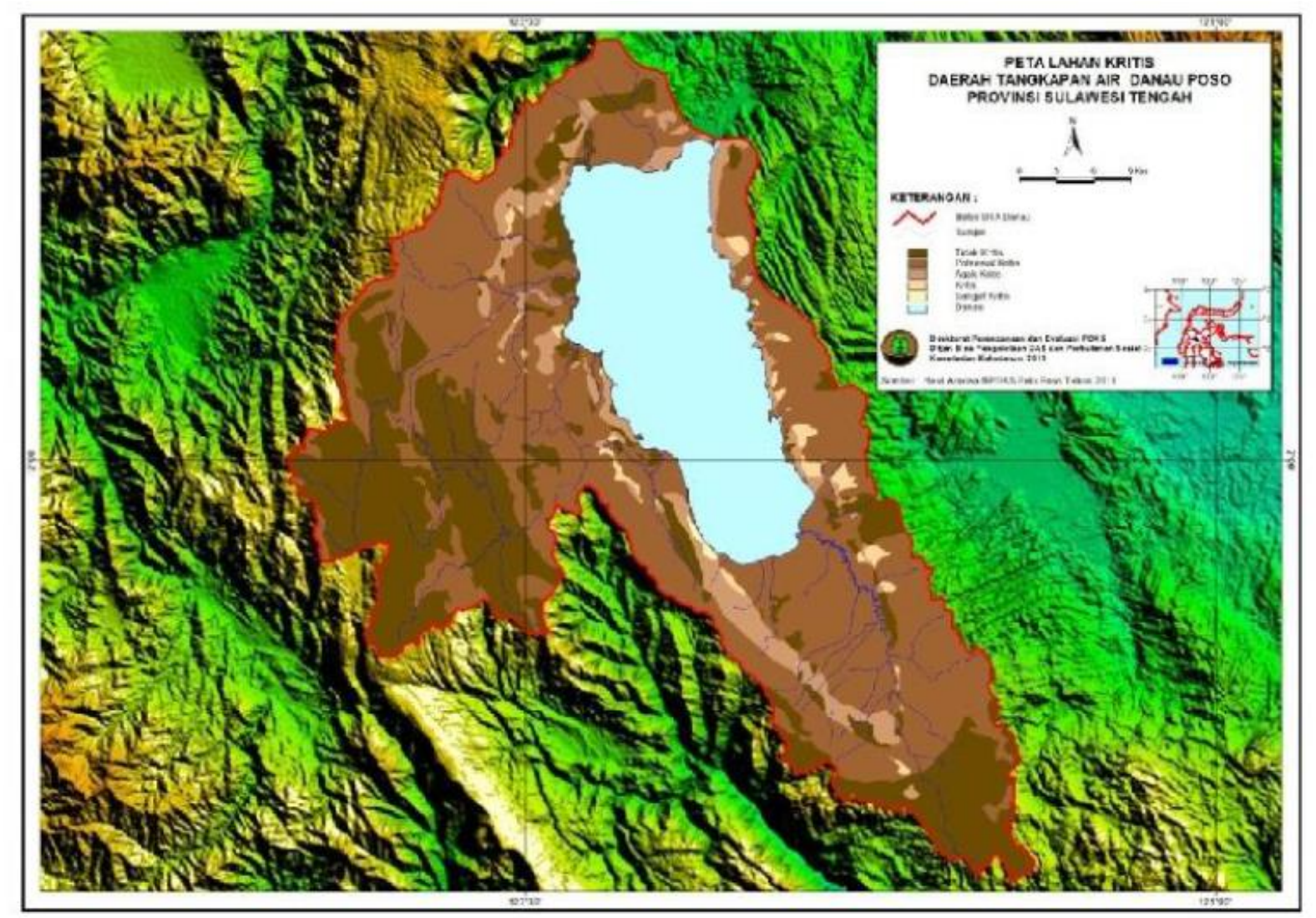

\section{Gambar 6. Peta Lahan Kritis pada DTA Danau Poso}

c. Tingkat kerusakan sempadan

Hasil survey dan analisis peta Citra Landsat 7 ETM menunjukkan bahwa telah terjadi kerusakan sempadan Danau Poso yang mengakibatkan danau mengalami pendangkalan (sedimentasi). Hal ini dikarenakan degradasi lahan pada hampir seluruh bagian tepian Danau Poso, terutama pada DTA-DTA yang kondisinya telah rusak seperti DTA Kodina-Boe dan DTA Meko. Pendangkalan yang terjadi cukup serius, dan diperkirakan telah mencapai luas 7.072,34 ha atau 19,23 \% dari total luas Danau Poso. Kategori pendangkalan berkisar mulai dari agak dangkal hingga dangkal.

Pendangkalan tersebut akan mempengaruhi daya tampung danau, dan pada akhirnya dapat mengurangi umur danau. Jika masalah pendangkalan ini tidak segera diatasi maka kapasitas tampung air pada danau akan semakin berkurang. Pada saat musim penghujan air danau mudah meluap, tetapi pada musim kemarau debit air akan mudah sekali mengalami penurunan. Dalam jangka panjang, pendangkalan dapat membuat danau berada pada kondisi suksesi, yaitu berubah dari ekosistem perairan menjadi bentuk ekosistem daratan (Isrun, 2009). 


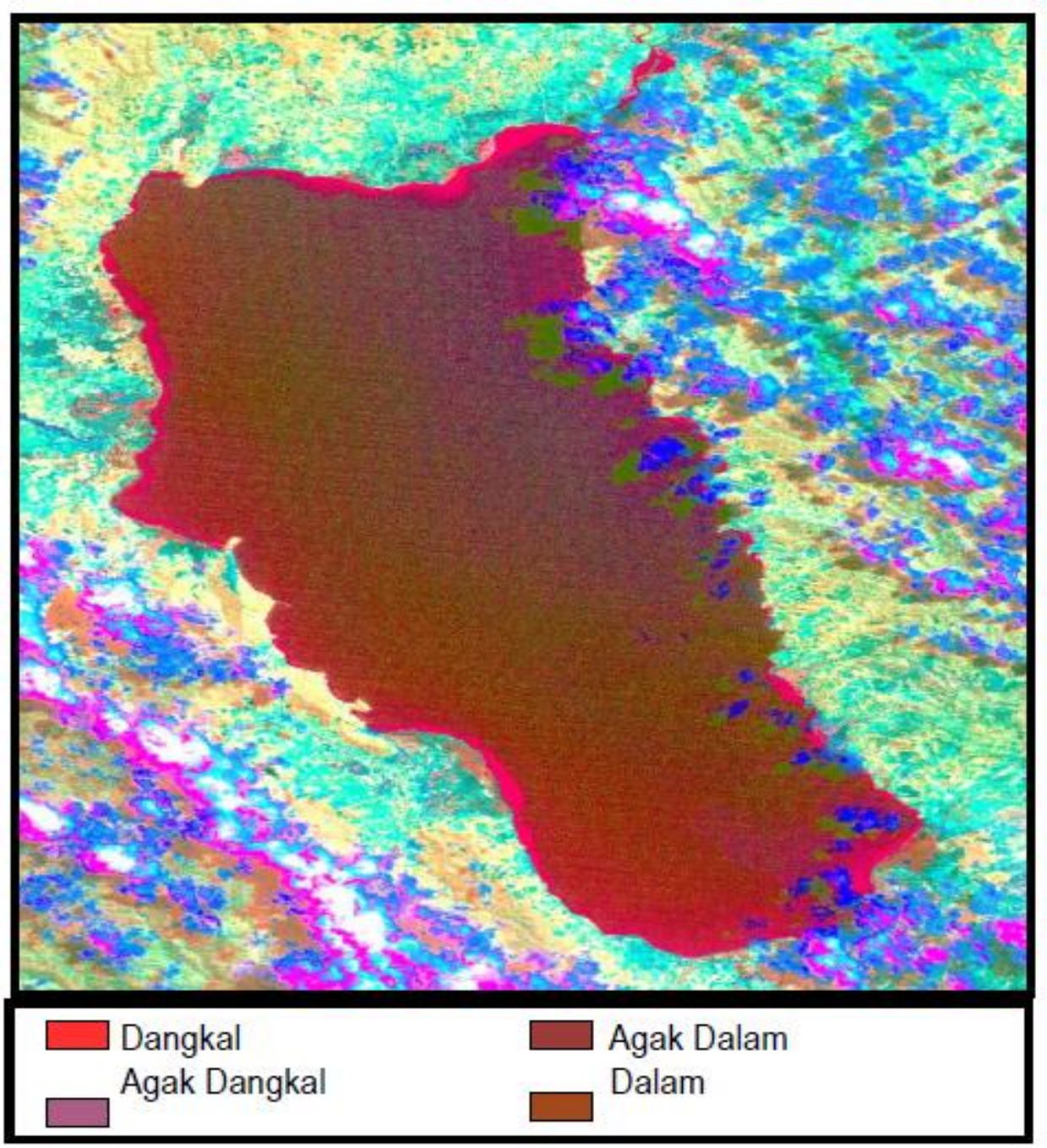

Gambar 7. Status Pendangkalan Danau Poso

Tabel 3. Prakiraan Tingkat Pendangkalan Danau Poso

\begin{tabular}{|c|l|r|r|r|r|}
\hline & & & \multicolumn{2}{c}{ Tingkat Pendangkalan } & \multirow{2}{*}{$\begin{array}{c}\text { Luas } \\
\text { No. }\end{array}$} \\
\cline { 4 - 5 } & \multicolumn{1}{|c|}{ Sub DTA } & $\begin{array}{c}\text { Luas Sub DTA } \\
\text { (ha) }\end{array}$ & $\begin{array}{c}\text { Agak } \\
\text { Dangkal } \\
<10 \mathrm{~m} \\
\text { (ha) }\end{array}$ & $\begin{array}{c}\text { Dangkal } \\
10-20 \mathrm{~m} \\
\text { (ha) }\end{array}$ & $\begin{array}{c}\text { pendangkalan } \\
\text { (ha) }\end{array}$ \\
\hline 1. & Kodina-Boe & $48.875,14$ & 197,06 & $2.355,14$ & $2.552,20$ \\
\hline 2. & Bancea-Panjo & $13.768,98$ & 232,77 & 204,04 & 436,81 \\
\hline 3. & Taipa & $3.727,95$ & 100,47 & 528,14 & 628,61 \\
\hline 4. & Meko & $46.793,16$ & 121,01 & $1.000,07$ & $1.121,08$ \\
\hline 5. & Salukaia & $7.108,53$ & 62,01 & & 62,01 \\
\hline 6. & Toinasa & $7.826,36$ & 214,66 & & 214,66 \\
\hline 7. & Saluopa- Mayakeli & $7.589,51$ & 525,46 & 208,07 & 733,53 \\
\hline 8. & Peura-Sangele & $3.497,26$ & 184,16 & 859,51 & $1.043,67$ \\
\hline 9. & Dulumai-Tokilo & $9.359,51$ & 75,85 & 203,92 & 279,77 \\
\hline & Total & $148.546,41$ & $1.713,45$ & $5.358,89$ & $7.072,34$ \\
\hline
\end{tabular}

Sumber : PPLH Untad (2010) 
2) Penurunan Kualitas Air Danau

Penelitian mengenai kualitas air Danau Poso masih sangat terbatas. Penelitian secara berkala perlu dilakukan untuk memperoleh data yang akurat dan komprehensif mengenai tingkat pencemaran yang terjadi pada perairan Danau Poso. Penelitian kualitas air Danau Poso pernah dilakukan oleh tim PPLH Universitas Tadulako pada tahun 2010, dan hasilnya ialah bahwa kualitas air danau pada beberapa indikator telah menunjukkan tingkat pencemaran yang cukup signifikan karena melebihi nilai ambang batas baku mutu kualitas air.

Tabel 4. Hasil Analisis Kualitas Air Danau Poso

\begin{tabular}{|c|c|c|c|c|c|c|c|}
\hline \multirow[t]{2}{*}{ No. } & \multirow[t]{2}{*}{ Indikator } & \multirow[t]{2}{*}{ Satuan } & \multirow[t]{2}{*}{ Hasil } & \multicolumn{4}{|c|}{ Baku Mutu Air } \\
\hline & & & & Kelas I & Kelas II & Kelas III & Kelas IV \\
\hline 1. & Suhu & ${ }^{\circ} \mathrm{C}$ & 30,40 & Deviasi 3 & Deviasi 3 & Deviasi 3 & Deviasi 5 \\
\hline 2. & TDS & $\mathrm{mg} / \mathrm{l}$ & 60,00 & 1000,00 & 1000,00 & 1000,00 & 1000,00 \\
\hline 3. & $\mathrm{pH}$ & $\mathrm{mg} / \mathrm{l}$ & 7,70 & $6-9$ & $6-9$ & $6-9$ & $5-9$ \\
\hline 4. & DO & $\mathrm{mg} / \mathrm{l}$ & 4,67 & 6,00 & 4,00 & 3,00 & 0,00 \\
\hline 5. & BOD & $\mathrm{mg} / \mathrm{l}$ & 3,30 & 2,00 & 3,00 & 6,00 & 12,00 \\
\hline 6. & COD & $\mathrm{mg} / \mathrm{l}$ & 10,08 & 10,00 & 25,00 & 50,00 & 100,00 \\
\hline 7. & Nitrit $\left(\mathrm{N}-\mathrm{NO}_{2}\right)$ & $\mathrm{mg} / \mathrm{l}$ & 0,024 & 0,06 & 0,06 & 0,06 & - \\
\hline 8. & Nitrat $\left(\mathrm{N}-\mathrm{NO}_{3}\right)$ & $\mathrm{mg} / \mathrm{l}$ & 0,40 & 0,50 & - & - & - \\
\hline 9. & Tembaga $(\mathrm{Cu})$ & $\mathrm{mg} / \mathrm{l}$ & 0,006 & 0,02 & 0,02 & 0,02 & 0,20 \\
\hline 10. & Seng (Zn) & $\mathrm{mg} / \mathrm{l}$ & 0,000 & 0,05 & 0,05 & 0,05 & 2,00 \\
\hline 11. & Timbal $(\mathrm{Pb})$ & $\mathrm{mg} / \mathrm{l}$ & 0,000 & 0,03 & 0,03 & 0,03 & 1,00 \\
\hline 12. & Mangan (Mn) & $\mathrm{mg} / \mathrm{l}$ & 0,000 & 0,10 & - & - & - \\
\hline 13. & Kadmium $(\mathrm{Cd})$ & $\mathrm{mg} / \mathrm{l}$ & 0,000 & 0,01 & 0,01 & 0,01 & 0,01 \\
\hline 14. & Besi (Fe) & $\mathrm{mg} / \mathrm{l}$ & 0,003 & 0,30 & - & - & - \\
\hline 15. & Sulfat $\left(\mathrm{SO}_{4}\right)$ & $\mathrm{mg} / \mathrm{l}$ & 0,650 & 400,00 & - & - & - \\
\hline
\end{tabular}

Sumber : PPLH Untad (2010)

Berdasarkan Peraturan Pemerintah Nomor 82 Tahun 2001 ditetapkan kriteria mutu air berdasarkan 4 kelas yang diklasifikasikan sebagai berikut :

a. Kelas I, yaitu air yang peruntukannya ialah air minum dan atau peruntukan lain yang mempersyaratkan mutu air yang sama dengan kegunaan tersebut.

b. Kelas II, yaitu air yang peruntukannya ialah prasarana/sarana rekreasi air, pembudidayaan ikan air tawar, peternakan, pengairan pertamanan, dan atau peruntukan lain yang mempersyaratkan mutu air yang sama dengan kegunaan tersebut.

c. Kelas III, yaitu air yang peruntukannya ialah pembudidayaan ikan air tawar, peternakan, pengairan pertamanan, dan atau peruntukan lain yang mempersyaratkan mutu air yang sama dengan kegunaan tersebut.

d. Kelas IV, yaitu air yang peruntukannya ialah pengairan pertamanan dan atau peruntukan lain yang mempersyaratkan mutu air yang sama dengan kegunaan tersebut (Herlambang, 2006).

Hasil analisis kualitas air Danau Poso dapat dijelaskan sebagai berikut :

a. Suhu mempengaruhi reaksi kimia dan biologi yang terjadi di dalam air. Kenaikan suhu air danau akan menimbulkan akibat berupa menurunnya jumlah oksigen terlarut di dalam air, meningkatnya kecepatan reaksi kimia, dan terganggunya kehidupan ikan dan 
hewan air lainnya. Peningkatan suhu juga menyebabkan terjadinya peningkatan dekomposisi bahan organik oleh mikroba (Djoharam et al, 2018). Suhu air Danau Poso yang rata-rata sebesar $30,40^{\circ} \mathrm{C}$ merupakan kondisi yang optimal bagi budidaya perikanan karena bagi kehidupan ikan di perairan tropis suhu optimal berkisar antara 28 $-32{ }^{\circ} \mathrm{C}$ (Kordi dan Tancung, 2007).

b. Parameter Total Dissolved Solid (TDS) atau Total Padatan Terlarut adalah bahan dalam air yang dapat melewati filter dengan ukuran 2 mikrometer atau lebih kecil dari ukuran rata-rata pori (Morintoh et al, 2015). Penyebab utama terjadinya TDS adalah bahan organik berupa ion-ion yang umum dijumpai di perairan, misalnya air buangan yang mengandung molekul sabun, deterjen, dan sulfaktan yang dapat larut dalam air (Harahap et al, 2013). Hasil analisis menunjukkan bahwa nilai TDS air Danau Poso sebesar $60,00 \mathrm{mg} / \mathrm{l}$ berada di bawah ambang baku mutu air yang berarti bahwa total padatan terlarut yang terdapat dalam perairan danau masih berada pada kisaran yang disyaratkan dalam baku mutu air.

c. Konsentrasi ion hidrogen atau $\mathrm{pH}$ merupakan faktor penting dalam perairan karena nilai $\mathrm{pH}$ akan menentukan sifat air menjadi asam atau basa. Perubahan $\mathrm{pH}$, baik ke arah asam atau basa, mempengaruhi kehidupan ikan dan hewan air lainnya. Sebagian besar biota air peka terhadap perubahan $\mathrm{pH}$ dan menyukai $\mathrm{pH}$ sekitar 7-7,5. Data pada Tabel 4 menunjukkan bahwa pH air Danau Poso berada pada kondisi netral $(7,70)$ dan masih berada pada kisaran yang disyaratkan dalam baku mutu air.

d. Parameter kandungan oksigen terlarut (Dissolved Oxygen/DO) sebesar 4,67 mg/l telah melewati nilai ambang baku mutu air untuk kelas II sampai IV, namun masih berada di bawah ambang baku mutu air kelas I. Kandungan oksigen terlarut di kawasan perairan sangat menentukan proses biokimia air, di mana oksigen terlarut dibutuhkan oleh organisme hidup untuk pernapasan, proses metabolisme, dan pertukaran zat yang kemudian menghasilkan energi untuk pertumbuhan dan perkembangbiakan. Di samping itu oksigen terlarut juga dibutuhkan untuk proses oksidasi bahan-bahan organik dan anorganik dalam proses aerobik.

Kebutuhan oksigen kimiawi (Chemical Oxygen Demand/COD) adalah jumlah total oksigen yang dibutuhkan untuk mengoksidasi bahan pencemar yang ada dalam air, sedangkan kebutuhan oksigen biologis (Biological Oxygen Demand/BOD) adalah banyaknya oksigen yang dibutuhkan oleh bakteri untuk menguraikan bahan pencemar dalam kondisi baku (Herlambang, 2006). Nilai BOD dan COD merupakan indikator pencemaran air oleh bahan-bahan organik yang berasal dari alam, aktivitas rumah tangga, dan aktivitas perekonomian. Hasil analisis kualitas air Danau Poso menunjukkan bahwa nilai BOD sebesar 3,30 mg/l dan nilai COD sebesar 10,08 mg/l telah melampaui ambang baku mutu air kelas I. Artinya ialah air Danau Poso telah mengalami pencemaran oleh bahan-bahan organik yang terutama berasal dari limbah rumah tangga dan industri. Nilai BOD dan COD yang tinggi dapat menurunkan nilai DO sehingga jumlah oksigen terlarut dalam air mengalami penurunan dan membahayakan kehidupan biota perairan (Pohan et al, 2016).

e. Hasil analisis menunjukkan kandungan nitrat $\left(\mathrm{N}-\mathrm{NO}_{3}\right)$ dan nitrit $\left(\mathrm{N}-\mathrm{NO}_{2}\right)$ pada air Danau Poso masing-masing sebesar 0,40 mg/l dan 0,024 mg/l. Nitrogen di perairan 
dapat berupa nitrogen anorganik dan organik. Nitrogen anorganik terdiri dari amonia $\left(\mathrm{NH}_{3}\right)$, amonium $\left(\mathrm{NH}_{4}\right)$, nitrit $\left(\mathrm{NO}_{2}\right)$, nitrat $\left(\mathrm{NO}_{3}\right)$, dan molekul nitrogen $\left(\mathrm{N}_{2}\right)$ dalam bentuk gas, sedangkan nitrogen organik terdiri dari protein dan asam amino. Nitrat $\left(\mathrm{NO}_{3}\right)$ merupakan bentuk utama nitrogen di perairan alami dan merupakan nutrien utama bagi pertumbuhan ganggang (algae) dan tumbuhan air seperti eceng gondok. Kandungan nitrit dan nitrat di kawasan perairan Danau Poso memang masih di bawah ambang baku mutu air yang disyaratkan, sehingga proses eutrofikasi belum banyak terjadi. Eutrofikasi adalah kondisi perairan yang subur karena tingginya kandungan nitrogen dalam bentuk nitrit, nitrat, dan amonia sehingga memacu perkembangan tumbuhan-tumbuhan air berupa ganggang dan eceng gondok. Perkembangan biota air yang tidak terkendali pada akhirnya akan berkontribusi pula pada pendangkalan badan perairan (Sudarmadji et al, 2012). Di perairan Danau Poso memang jarang dijumpai tumbuhan air seperti ganggang dan eceng gondok. Namun demikian tidak tertutup kemungkinan pengaruh limbah-limbah pertanian yang masuk ke badan air di sekitar Danau Poso akan meningkatkan proses eutrofikasi.

f. Belum ditemukan adanya pencemaran air Danau Poso oleh logam-logam berat seperti seng $(\mathrm{Zn})$, timbal $(\mathrm{Pb})$, mangan $(\mathrm{Mn})$, dan kadmium $(\mathrm{Cd})$. Walaupun terdapat unsur tembaga $(\mathrm{Cu})$ dan besi $(\mathrm{Fe})$ serta senyawa sulfat $\left(\mathrm{SO}_{4}\right)$ dalam hasil analisis, tetapi kadarnya sangat kecil dan masih berada di bawah ambang baku mutu air.

3) Ancaman Terhadap Keberadaan Ikan Sidat Sebagai Ikan Endemik Danau Poso

Perairan Danau Poso dan Daerah Aliran Sungai (DAS) Poso yang terdiri dari Sungai Poso yang bermuara di Teluk Tomini beserta anak-anak sungainya merupakan habitat dan kawasan ruaya (migrasi) ikan sidat. Jenis-jenis ikan sidat yang hidup di perairan Danau Poso adalah Anguilla marmorata, Anguilla mauritania, dan Anguilla celebensis (Krismono dan Kartamihardja, 2012).

Ikan sidat merupakan ikan katadromus, yaitu ikan yang hidup di perairan air tawar (sungai/danau), di mana induk sidat dewasa akan bermigrasi ke laut untuk melakukan pemijahan, dan setelah itu anakannya akan kembali lagi ke perairan tawar untuk melanjutkan siklus hidupnya. Keberadaan ikan sidat di perairan Danau Poso dan DAS Poso merupakan berkah bagi nelayan yang berada di pinggiran danau dan sungai tersebut. Hal ini disebabkan harga jual dan permintaan yang tinggi terhadap ikan sidat. Permintaan terhadap ikan sidat bukan hanya berasal dari dalam Kabupaten Poso saja, tetapi juga dari luar daerah bahkan dari luar negeri (Sugianti dan Saepulloh, 2011).

Akan tetapi hasil penelitian Krismono dan Kartamihardja (2012) menunjukkan bahwa selama periode tahun 2010 - 2012 anakan ikan sidat (glass eel) yang melakukan migrasi (ruaya) dari sungai Poso ke Danau Poso menurun sekitar 1 juta ekor per tahun, yaitu dari 36 juta ekor per tahun menjadi 35 juta ekor per tahun. Potensi induk sidat menurun sekitar 3.000 ekor per tahun, yaitu dari 9.000 ekor menjadi 6.000 ekor per tahun. Haryani dan Hehanussa (2000) menyatakan bahwa pada tahun 1970 produksi ikan sidat yang diestimasi berdasarkan alat tangkap yang terpasang di Sungai Poso tercatat sebesar 22 ton, meningkat pada tahun 1980 menjadi 41,5 ton tetapi menurun menjadi 30, 5 ton pada tahun 1998. Pada periode tahun 2004 - 2005, hasil tangkapan ikan sidat menurun menjadi sebesar 22 ton 
(Husnah et al, 2008), sedangkan pada tahun 2006 hasil tangkapan ikan sidat hanya sebesar 9,1 ton (Suryono dan Badjoeri, 2013).

Terdapat beberapa faktor utama yang mengganggu kelestarian ikan sidat di perairan Danau Poso berdasarkan hasil penelitian Krismono dan Kartamihardja (2012), yaitu :

a. Penangkapan berlebihan benih sidat

Benih sidat (glass eel) yang ditangkap dengan menggunakan bubu ataupun seser oleh nelayan setempat kemudian ditampung sebagai persediaan benih sidat yang selanjutnya dijual kepada pengusaha pembesaran sidat. Ikan sidat setelah dibesarkan kemudian dijual, baik di dalam negeri maupun ke luar negeri seperti Jepang. Penangkapan benih sidat secara besar-besaran di muara Poso merupakan salah satu penyebab berkurangnya jumlah benih sidat yang melakukan ruaya menuju ke Danau Poso.

b. Pembendungan Sungai Poso untuk PLTA

Pembendungan Sungai Poso di Sulewana ditujukan untuk beroperasinya Pembangkit Listrik Tenaga Air (PLTA) guna keperluan produksi energi listrik. Tetapi akibat dari pembendungan tersebut ialah banyaknya anakan sidat (elver eel) yang tidak bisa naik ke Danau Poso karena tertahan di Sulewana. Demikian pula induk sidat dari Danau Poso tidak dapat turun ke muara sungai karena adanya saringan di bendungan. Kondisi ini akan mengganggu aktivitas ruaya ikan sidat, baik yang berruaya dari Danau Poso ke muara maupun yang sebaliknya yang berruaya dari muara ke danau.

c. Penangkapan intensif induk ikan sidat

Data hasil tangkapan ikan sidat dari pengumpul yang menggunakan waya masapi (pagar perangkap ikan sidat) menunjukkan bahwa ikan sidat paling banyak tertangkap pada bulan Maret hingga April dengan rata-rata tangkapan mencapai 30 ekor setiap malamnya. Hal ini berkaitan dengan ketinggian permukaan air Danau Poso yang mencapai maksimum karena tingginya curah hujan pada bulan-bulan tersebut. Pada bulan-bulan lainnya, jumlah ikan sidat yang tertangkap hanya berkisar antara 2 - 3 ekor bahkan kadang-kadang tidak tertangkap sama sekali. Penangkapan ikan sidat dewasa di Tentena yang merupakan outlet Danau Poso apabila dilakukan sangat intensif dengan waya masapi yang menutup seluruh badan air dapat menyebabkan menurunnya populasi ikan sidat dewasa yang akan berruaya ke laut untuk melakukan pemijahan.

d. Rendahnya tingkat kesadaran masyarakat terhadap konservasi ikan sidat Hasil penelitian yang dilakukan pada tahun 2012 oleh Krismono dan Kartamihardja dari Balai Riset Pemulihan Sumber Daya Ikan, Jatiluhur menunjukkan bahwa nelayan perairan umum daratan di Muara Sungai Poso, Sungai Poso, Sungai Pandiri, dan Danau Poso rata-rata berpendidikan SD (54,2 \%) sampai dengan SMP (45,5 \%). Meskipun berpendidikan rendah, namun dari segi pengalaman menjadi nelayan, sebagian besar sudah menjadi nelayan selama lebih dari 20 tahun sehingga mereka sangat memahami karakteristik perilaku ikan sidat, baik pada musim panen maupun musim ruayanya. Wawancara terhadap 476 orang nelayan tentang status ikan sidat dan langkah-langkah konservasi yang diperlukan guna melestarikan usaha penangkapan ikan dan keberadaan ikan sidat di DAS Poso, menunjukkan hasil yang sangat memprihatinkan. Hanya sekitar $20 \%$ dari para nelayan yang tahu dan mengerti tentang perlunya konservasi ikan sidat, $25 \%$ mengerti tetapi tidak tahu, $25 \%$ tahu dan tidak mengerti, dan $30 \%$ masa 
bodoh. Walaupun demikian, setelah para peneliti menjelaskan tentang pentingnya konservasi ikan sidat demi keberlanjutan usaha para nelayan dan kelestarian sumberdaya ikan sidat, sebagian besar dari para nelayan bersedia untuk mendukung kegiatan konservasi ikan sidat di perairan Danau Poso dan DAS Poso.
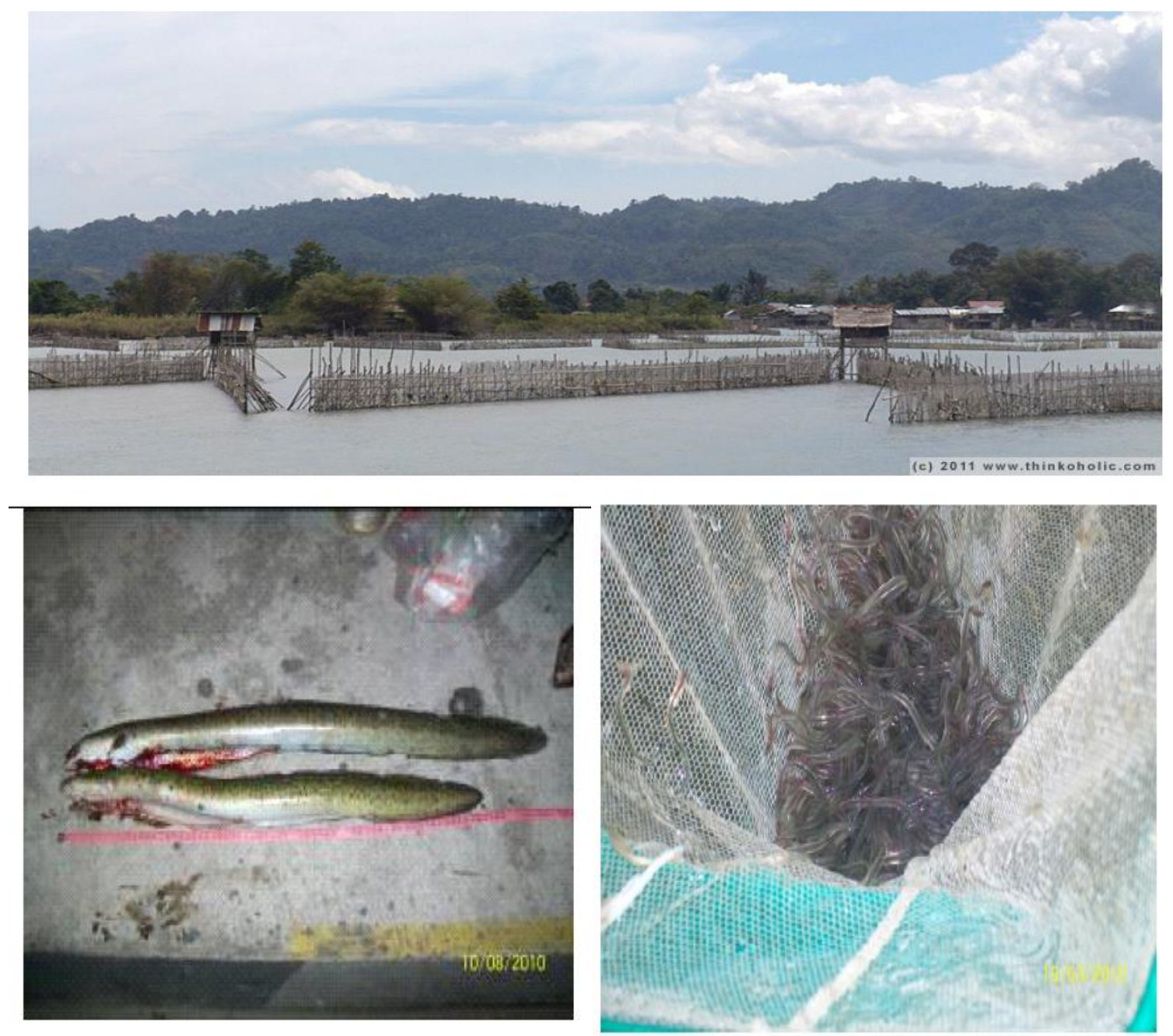

Gambar 8. Waya Masapi, Sidat Dewasa, dan Anakan Sidat

\section{UPAYA-UPAYA PENANGGULANGAN TERHADAP GANGGUAN KESEIMBANGAN EKOSISTEM DANAU POSO}

Penanggulangan terhadap gangguan keseimbangan ekosistem Danau Poso memerlukan kajian-kajian yang terintegrasi dari berbagai aspek (ekonomi, sosial, dan lingkungan hidup) serta keterlibatan secara menyeluruh dari seluruh pemangku kepentingan (stakeholders), yaitu pemerintah, swasta, akademisi, dan masyarakat (Dewanto et al, 2012). Oleh karena itu maka dari setiap aktivitas pengelolaan danau dapat diketahui dampak penting yang mungkin terjadi serta disusunnya rencana-rencana strategis guna meminimalkan dampak negatif pengelolaan terhadap kehidupan masyarakat dan kelestarian sumberdaya alam Danau Poso. 
Ruang lingkup penyelamatan ekosistem Danau Poso diawali dengan mengidentifikasi masalah guna menemukan dan mengenali akar permasalahan dari kondisi danau saat ini. Degradasi lahan di sekitar kawasan Danau Poso terutama pada DTA-nya ditandai dengan semakin meluasnya lahan kritis sehingga terjadi erosi pada lereng-lereng curam, pada lahan yang digunakan untuk pertanian maupun peruntukan lain seperti pemukiman dan pertambangan. Terjadinya fenomena ini tidak terlepas dari kurang efektifnya pengelolaan Daerah Aliran Sungai (DAS), terutama karena tidak adanya keterpaduan tindakan dan upaya yang dilakukan oleh berbagai sektor, instansi, atau pihak-pihak yang berkepentingan dengan DAS. Oleh karena itu, pendekatan menyeluruh dan terpadu sangat diperlukan dalam mengurangi degradasi lahan di kawasan Danau Poso (KLH, 2014). Guna mencapai hal tersebut maka dalam Kesepakatan Bali 2009 telah ditetapkan Gerakan Penyelamatan Danau (GERMADAN) melalui 3 pendekatan yang saling mendukung dan terintegrasi seperti pada gambar berikut ini.

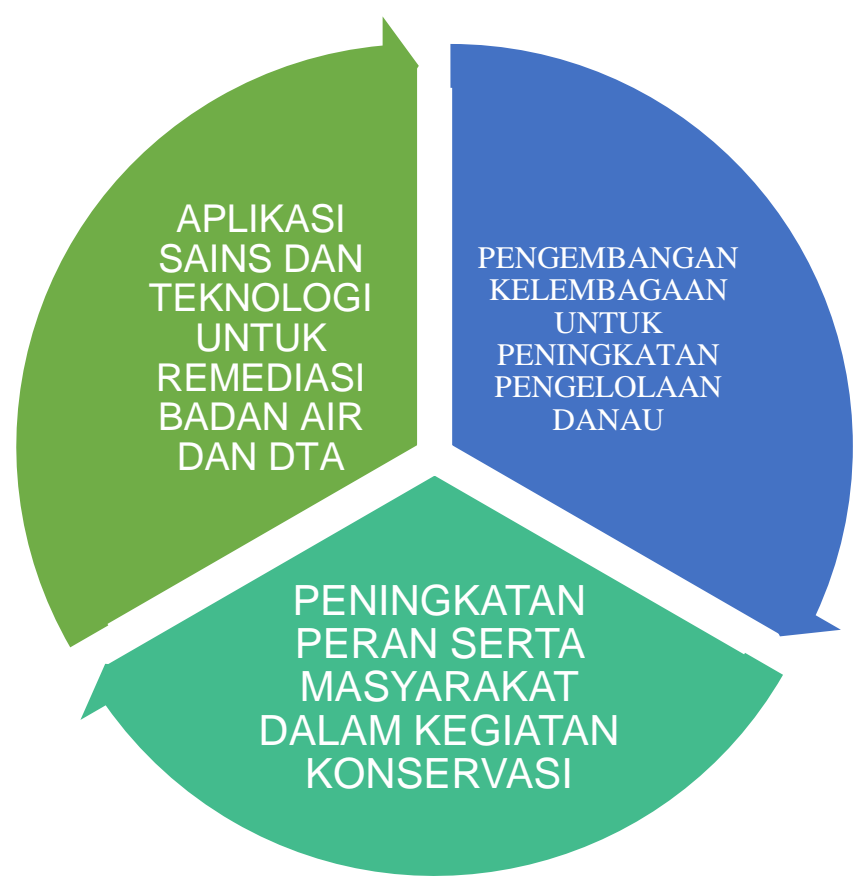

\section{Gambar 9. Pendekatan untuk Penyelamatan Danau Poso}

Berdasarkan hal tersebut, maka upaya-upaya yang dapat dilakukan sebagai solusi untuk mengatasi gangguan terhadap keseimbangan ekosistem dalam rangka penyelamatan Danau Poso ialah sebagai berikut :

1) Penyelamatan ekosistem DTA dan DAS

Secara alami, danau akan mengalami pendangkalan walaupun memerlukan waktu yang relatif lama. Pendangkalan danau dapat dipercepat karena aktivitas manusia di kawasan DTA yang menyebabkan tingginya laju sedimentasi dan erosi. DTA dan DAS yang mengalami kerusakan menyebabkan fluktuasi debit air yang tinggi sehingga menimbulkan banjir pada musim hujan dan berkurangnya debit air secara drastis di musim kemarau. 
Penyelamatan ekosistem DTA dan DAS dapat dilakukan dengan cara :

a. Pengumpulan data mengenai degradasi lahan yang terjadi pada kawasan Danau Poso. Data yang dikumpulkan dari setiap lokasi DTA dan DAS meliputi letak, luas, status lahan berdasarkan geografi dan administrasi pemerintahan, kondisi penutupan lahan, tipe kemiringan lereng, tingkat erosi, manajemen konservasi (jika ada), dan produktivitas lahan, khususnya pada kawasan budidaya pertanian di sekitar danau. Kegiatan ini memerlukan pendanaan untuk pengadaan tenaga-tenaga ahli atau peneliti serta peralatan untuk menunjang observasi. Berdasarkan data maka dapat disusun laporan mengenai analisis terhadap nilai-nilai parameter kerusakan lahan, di mana hasil analisis dapat digunakan untuk penyusunan rencana program kegiatan pencegahan dan pengendalian degradasi lahan di kawasan Danau Poso.

b. Melakukan Kajian Lingkungan Hidup Strategis (KLHS) secara komprehensif pada kawasan Danau Poso. KLHS dilakukan terhadap Rencana Tata Ruang Wilayah (RTRW) provinsi dan kabupaten yang termasuk pada wilayah pengelolaan Danau Poso, serta terhadap kebijakan, rencana dan atau program yang secara potensial berdampak negatif terhadap kondisi Danau Poso. Berbeda dengan Analisis Mengenai Dampak Lingkungan (Amdal) yang menangani aspek hilir atau kegiatan, KLHS melakukan kajian terhadap aspek hulu terkait dengan kebijakan, rencana, dan atau program. Oleh karena itu KLHS sangat diperlukan karena mengkaji hal-hal yang terkait dengan upaya penyelamatan danau pada tataran kebijakan atau pada tataran yang paling dini. Hal-hal yang berkaitan dengan peraturan dan pemberian izin pada usaha-usaha di DTA dapat terdeteksi melalui KLHS sehingga dapat dilakukan upaya-upaya pencegahan. Usahausaha di DTA yang sangat berpotensi mengancam kondisi danau ialah perkebunan skala besar, eksploitasi hutan, dan pertambangan. Selain itu, pendekatan KLHS yang lebih bersifat partisipatif akan menumbuhkan rasa tanggung jawab berbagai pihak terhadap penyelamatan danau. KLHS memerlukan pendanaan untuk pengalokasian SDM berupa tenaga ahli atau peneliti, proses pembahasan antar pemangku kepentingan, dan pengadaan peralatan guna menunjang observasi. KLHS yang disusun selanjutnya diimplementasikan pada kebijakan, rencana, dan atau program yang terkait dengan kondisi Danau Poso sehingga dapat digunakan sebagai instrumen penangkal paling awal dalam perencanaan pengelolaan danau. KLHS juga dapat menjadi acuan dalam penyusunan rencana program kegiatan pencegahan dan pengendalian degradasi ekosistem di kawasan Danau Poso. Pembuatan kajian dapat dilakukan oleh dinas/instansi terkait dengan melibatkan tokoh-tokoh masyarakat, tokoh-tokoh agama, lembaga pendidikan tinggi, lembaga swadaya masyarakat, pemerintah kecamatan, dan desa/kelurahan.

c. Melaksanakan strategi penanganan kawasan DTA yang meliputi penerapan Rencana Tata Ruang Wilayah Kabupaten (RTRWK) secara tegas dan konsisten pada ke - 9 wilayah Sub DTA, melakukan percepatan dan peningkatan kapasitas rehabilitasi hutan dan lahan di wilayah-wilayah Sub DTA yang telah mengalami degradasi lahan, dan menerapkan sistem zonasi pada kawasan hutan lindung, terutama pada kawasan cagar alam. 
d. Penerapan usahatani konservasi pada kawasan-kawasan Sub DTA. Usahatani konservasi pada hakikatnya merupakan pendekatan usahatani terpadu yang menekankan pengembangan kombinasi teknik budidaya/usahatani lahan kering dengan teknik konservasi tanah (vegetatif dan mekanik) secara efektif untuk menjamin pemanfaatan lahan, air, dan vegetasi secara lestari dan menguntungkan (Nuraeni et al, 2013). Menurut Sutrisna et al (2010), teknik konservasi tanah secara vegetatif dapat dilakukan dengan cara menerapkan pola tanam secara bergilir, penggunaan mulsa sebagai penutup tanah, penanaman pohon sebagai pagar hidup, dan penanaman rumput pada tepi teras atau guludan untuk menahan erosi. Teknik konservasi tanah secara mekanik dapat dilakukan dengan cara pembuatan teras pada lahan-lahan pertanian yang terletak pada bagian lereng, pembuatan penampungan air hujan, dan pembuatan saluran drainase untuk membuang kelebihan air dari lahan pertanian. Penerapan usahatani konservasi membutuhkan kajian-kajian penelitian secara mendalam guna menghasilkan teknik yang bersifat spesifik lokasi.

2) Pengendalian pencemaran, pemantauan, dan evaluasi kualitas air Danau Poso

a. Pengendalian pencemaran air Danau Poso

Kondisi kualitas air Danau Poso telah mengalami penurunan akibat adanya buangan limbah domestik, limbah pertanian, aktivitas budidaya perikanan yang dilakukan di perairan danau, dan sedimentasi danau akibat erosi di daerah hulu. Kualitas air danau perlu diukur secara berkala melalui pengambilan sampel pada bagian inlet (hulu), pertengahan danau, tepian danau, dan outlet (hilir), demikian pula identifikasi terhadap biota air yang ada pada ekosistem Danau Poso. Tersedianya data akurat mengenai kualitas air danau merupakan dasar bagi penyusunan perencanaan pengelolaan dan pemulihan lingkungan ekosistem Danau Poso.

b. Pemantauan dan evaluasi kualitas air Danau Poso

Pemantauan kualitas air sangat diperlukan mengingat kondisi perairan Danau Poso yang sudah mulai tercemar oleh buangan limbah domestik, pertanian, dan industri. Pemantauan secara berkala perlu dilakukan untuk mendapatkan data yang komprehensif, sehingga dampak yang mungkin ditimbulkan oleh adanya berbagai aktivitas masyarakat dapat dikurangi melalui penerapan kebijakan yang berwawasan lingkungan. Upaya-upaya pengendalian pencemaran, pemantauan, dan evaluasi kualitas air danau memerlukan pendanaan untuk alokasi tenaga ahli dan peneliti serta peralatan penelitian. Hasil yang diharapkan ialah tersedianya data akurat kualitas air dan daya tampung beban pencemaran air Danau Poso dalam rangka penyusunan rencana pengelolaan dan pemulihan lingkungan perairan Danau Poso.

Dengan diketahuinya kualitas air dan daya tampung beban pencemaran, maka pemerintah daerah dapat mengeluarkan regulasi mengenai penetapan zona yang dapat dimanfaatkan untuk kegiatan industri, lingkungan perumahan, dan kegiatan pertanian. Adanya penetapan zona tersebut dapat memberikan dampak positif terhadap kualitas air danau, sehingga ekosistem danau akan memiliki kemampuan memulihkan diri dari pencemaran yang masuk ke badan perairan. 
3) Pelestarian dan optimasi pemanfaatan sumberdaya ikan sidat

Berdasarkan hasil penelitian Krismono dan Putri (2012), langkah-langkah pelestarian dan optimasi sumberdaya ikan sidat di perairan Danau Poso dapat ditempuh melalui beberapa cara, yaitu :

a. Menetapkan kawasan konservasi ikan sidat, baik kawasan untuk perlindungan induk maupun anakannya. Oleh karena daerah ruaya ikan sidat di Sungai Poso telah terganggu dengan adanya bendungan PLTA di daerah Sulewana, maka alternatif lain yang dapat dilakukan ialah menetapkan kawasan konservasi ikan sidat di Sungai Pandiri yang memiliki potensi ikan sidat yang cukup besar.

b. Menyediakan "eel ladder" atau "fish way" yang akan berfungsi sebagai lokasi ruaya ikan sidat, baik ruaya induk yang menuju laut maupun anakan yang akan berruaya ke hulu menuju Danau Poso. Rancangan "eel ladder" atau "fish way" ini bersifat khusus, disesuaikan dengan sifat biologi dan kemampuan renang ikan sidat.

c. Penebaran kembali (restocking) benih sidat di Danau Poso. Benih sidat dapat dihasilkan dari pembesaran di usaha pendederan, sedangkan glass eel dapat diperoleh dari penangkapan di muara Sungai Poso. Upaya restocking ditujukan untuk meningkatkan stok ikan sidat di Danau Poso yang ruayanya terganggu akibat pembendungan PLTA.

d. Pengaturan penangkapan, baik induk sidat yang ditangkap di outlet Danau Poso dengan waya masapi maupun penangkapan glass eel di muara Sungai Poso. Alat tangkap waya masapi diusahakan tidak menutupi seluruh badan air outlet Danau Poso, sedangkan penangkapan glass eel di muara Sungai Poso perlu dibatasi.

e. Pembentukan dan peningkatan kapasitas kelembagaan pengelola yang melibatkan peran serta masyarakat untuk menjamin terlaksananya konservasi sumberdaya ikan sidat.

4) Pengaturan pengelolaan terhadap pemanfaatan sumberdaya air Danau Poso

Secara ekosistem, perairan danau memiliki fungsi sebagai berikut :

a. Sebagai sumber plasma nutfah yang berpotensi menyumbang bahan genetik,

b. Sebagai tempat berlangsungnya siklus hidup berbagai jenis flora dan fauna yang penting,

c. Sebagai sumber air yang dapat digunakan secara langsung oleh masyarakat sekitarnya untuk aktivitas rumah tangga, industri, dan pertanian,

d. Sebagai tempat penyimpanan kelebihan air yang berasal dari air hujan, aliran permukaan, sungai-sungai, atau dari sumber-sumber air bawah tanah,

e. Sebagai pemelihara iklim mikro, di mana keberadaan ekosistem danau dapat mempengaruhi kelembaban udara dan curah hujan daerah setempat,

f. Sebagai sarana transportasi untuk memindahkan hasil-hasil pertanian dari satu tempat ke tempat lainnya,

g. Sebagai penghasil energi listrik melalui PLTA, dan

h. Sebagai sarana rekreasi dan obyek pariwisata.

Pengelolaan danau harus dilaksanakan secara terencana, agar potensi danau dapat dimanfaatkan seoptimal mungkin. Kegiatan-kegiatan pengelolaan danau diprioritaskan pada kawasan danau yang memiliki potensi pemanfaatan tinggi, juga pada kawasan yang telah mengalami degradasi secara serius. Di samping itu, kegiatan pengelolaan danau harus ditujukan bagi terciptanya kesejahteraan masyarakat dengan memperhatikan pula aspek 
keseimbangan ekologinya. Karenanya dibutuhkan penyusunan master plan tata guna air danau bagi aktivitas pemanfaatan air danau untuk keperluan irigasi, air bersih, perikanan, PLTA, dan keperluan-keperluan lainnya. Adanya master plan memungkinkan tertatanya pemanfaatan sumberdaya air danau sesuai kebutuhan sektoral.

5) Peningkatan peran dan partisipasi masyarakat dalam penyelamatan ekosistem Danau Poso Masyarakat memiliki peran yang sangat penting dalam keberhasilan upaya penyelamatan ekosistem Danau Poso. Kearifan lokal, pengetahuan, dan keterampilan yang dimiliki masyarakat setempat merupakan faktor-faktor yang dapat dimanfaatkan dalam tindakan pengelolaan dan konservasi Danau Poso. Upaya penyelamatan ekosistem danau perlu melibatkan partisipasi aktif dan peran serta masyarakat, karena keikutsertaan masyarakat akan menumbuhkan dan memperkuat rasa memiliki dan menghargai ekosistem Danau Poso sebagai aset sumberdaya alam yang perlu dilindungi. Hal ini akan berdampak pada pemanfaatan sumberdaya alam Danau Poso secara lestari oleh masyarakat, sehingga secara ekonomi masyarakat tetap memperoleh pendapatan yang berkelanjutan.

Peningkatan peran dan partisipasi masyarakat dapat ditempuh dengan cara-cara berupa :

a. Pembentukan kelompok-kelompok peduli lingkungan Danau Poso untuk meningkatkan kesadaran masyarakat akan pentingnya pelestarian ekosistem Danau Poso.

b. Pengkajian nilai-nilai kearifan lokal masyarakat yang dapat dimanfaatkan dalam upaya pelestarian ekosistem Danau Poso.

c. Penerapan dan pengembangan pertanian berkelanjutan dan ramah lingkungan (sustainable and environmental friendly agriculture), melalui pembentukan kelompokkelompok tani ramah lingkungan yang menerapkan praktik-praktik pertanian konservasi untuk meminimalisir dampak negatif aktivitas pertanian terhadap kelestarian ekosistem danau.

d. Pelaksanaan bimbingan dan penyuluhan kepada masyarakat secara terprogram dan berkala mengenai keberadaan Danau Poso dari aspek sumberdaya alam dan lingkungan, sosial, dan ekonomi.

\section{PENUTUP}

Danau Poso sebagai aset sumberdaya alam perlu dimanfaatkan dan dikelola bagi kepentingan kesejahteraan masyarakat di sekitarnya. Akan tetapi pemanfaatan dan pengelolaan Danau Poso melalui berbagai aktivitas manusia telah menimbulkan gangguan terhadap keseimbangan ekosistem yang merupakan ancaman terhadap kelestarian ekosistem danau. Perlu upaya-upaya penanggulangan terhadap gangguan keseimbangan ekosistem yang dilakukan secara terpadu oleh pemerintah, dunia usaha, akademisi, dan masyarakat, agar Danau Poso tetap dapat berfungsi secara ekologis dan ekonomis. 


\section{REFERENSI}

BPS Poso, 2017. Kecamatan Pamona Puselemba dalam Angka 2017. Badan Pusat Statistik Kabupaten Poso. Poso.

Dewanto, D., Z. Lantiunga, dan D. Limbong, 2012. Pengembangan Sistem Informasi dan Analisis Geomorfometris Daerah Aliran Sungai Danau Poso. Jurnal Riset Unkrit. 1 (1) : $20-30$.

Djoharam, V., E. Riani, dan M. Yani, 2018. Analisis Kualitas Air dan Daya Tampung Beban Pencemaran Sungai Pesanggrahan di Wilayah Provinsi DKI Jakarta. Jurnal Pengelolaan Sumberdaya Alam dan Lingkungan. 8 (1) : 127 - 133.

Harahap, A., E. Naria, dan D.N. Santi, 2013. Analisis Kualitas Air Sungai Akibat Pencemaran Tempat Pembuangan Akhir Sampah Batu Bola dan Karakteristik Serta Keluhan Kesehatan Pengguna Air Sungai Batang Ayumi di Kota Padangsidimpuan Tahun 2012. Jurnal Lingkungan dan Kesehatan Kerja. 2 (2) : $1-9$.

Haryani, S.G. dan P.E. Hehanussa, 2000. Preliminary Study of Eel Fish in Lake Poso, Sulawesi Island, Indonesia. Hydrobiol. $12: 75-80$.

Herlambang, A., 2006. Pencemaran Air dan Strategi Penanggulangannya. JAI. 2 (1) : 16 29.

Husnah, W.H. Tjahjo, A. Nastiti, dan Sulistiono, 2008. Status Keanekaragaman Hayati Sumberdaya Perikanan Perairan Umum di Sulawesi. Balai Riset Perikanan Perairan Umum, Pusat Riset Perikanan Tangkap. Badan Riset Kelautan dan Perikanan.

Isrun, 2009. Analisis Tingkat Kerusakan Lahan pada Beberapa Sub DAS di Kawasan Danau Poso. Jurnal Media Litbang Sulteng. 2 (1) : 67 - 74.

KLH, 2011. Profil 15 Danau Prioritas Nasional. Kementerian Lingkungan Hidup Republik Indonesia. Jakarta.

KLH, 2014. Gerakan Penyelamatan Danau (Germadan) Poso. Kementerian Lingkungan Hidup Republik Indonesia. Jakarta.

Kordi, M.G.H.K. dan A.B. Tancung, 2007. Pengelolaan Kualitas Air dalam Budidaya Perairan. Rineka Cipta. Jakarta.

Krismono dan E.S. Kartamihardja, 2012. Optimasi Pemanfaatan dan Konservasi Stok Ikan Sidat (Anguilla sp) di DAS Poso Sulawesi Tengah. Jurnal Kebijakan Perikanan Indonesia. 4 (1) : 9-16. 
Krismono dan M.R.A. Putri, 2012. Variasi Ukuran dan Sebaran Tangkapan Ikan Sidat (Anguilla marmorata) di Sungai Poso, Sulawesi Tengah. Jurnal Penelitian Perikanan Indonesia. $18(2): 85-92$.

Lukman dan I. Ridwansyah, 2003. Kondisi Daerah Tangkapan dan Ciri Morfometri Danau Lindu Sulawesi Tengah. Jurnal Oseanologi dan Limnologi Indonesia. 35 : 11 - 20.

Lukman dan I. Ridwansyah, 2009. Telaah Kondisi Fisik Danau Poso dan Prediksi Ciri Ekosistem Perairannya. Jurnal Limnotek. 16 (2) : 64 - 73.

Morintoh, P., J.F. Rumampuk, dan F. Lintong, 2015. Analisis Perbedaan Uji Kualitas Air Sumur di Daerah Dataran Tinggi Kota Tomohon dan Dataran Rendah Kota Manado Berdasarkan Parameter Fisika. Jurnal e-Biomedik. 3 (1) : 424 - 429.

Nuraeni, Sugiyanto, dan Zaenal, 2013. Usahatani Konservasi di Hulu DAS Jeneberang (Studi Kasus Petani Sayuran di Hulu DAS Jeneberang Sulawesi Selatan). Jurnal Manusia dan Lingkungan. 20 (2) : $173-183$.

Pangesti, D.R., C. Kristijatno, S. Qamariah, dan Syaifudin, 1995. Penelitian Perilaku Sungai Poso Sulawesi Tengah. Proyek Penelitian Pengendalian Persungaian. Balai Penyelidikan Sungai, Puslitbang Pengairan - PU. 96 hal.

Peraturan Pemerintah Nomor 82 Tahun 2001 tentang Pengelolaan Air dan Pengendalian Pencemaran Air.

Pohan, D.A.S., Budiyono, dan Syafrudin, 2016. Analisis Kualitas Air Sungai Guna Menentukan Peruntukan Ditinjau dari Aspek Lingkungan. Jurnal Ilmu Lingkungan. 14 (2) : $63-71$.

Sudarmadji, S. Wantasen, dan S. Suprayogi, 2012. Dampak Penggunaan Lahan Daerah Tangkapan dan Pemanfaatan Perairan Danau pada Eutrofikasi dan Keberlanjutan Danau Tondano Provinsi Sulawesi Utara. Prosiding Seminar Nasional Limnologi VI. 16 Juli 2012, Bogor, Indonesia. Hal. 1 - 16.

Sugianti, Y., dan H. Saepulloh, 2011. Keragaan Alat Tangkap dan Pengaruhnya Terhadap Sumberdaya Ikan Sidat (Anguilla spp) di DAS Poso. Prosiding Forum Nasional Pemacuan Sumber Daya Ikan III. 18 Oktober 2011. Hal. 1 - 7.

Suryono, T. dan M. Badjoeri, 2013. Kualitas Air pada Uji Pembesaran Larva Ikan Sidat (Anguilla spp) dengan Sistem Pemeliharaan yang Berbeda. Jurnal Limnotek. 20 (2) : 169 -177 . 
Sutrisna, N., S.R.P. Sitorus, B. Pramudya, dan Harianto, 2010. Alternatif Model Usahatani Konservasi di Hulu Sub DAS Cikapundung. Jurnal Hortikultura. 20 (3) : 223 - 240. 